\title{
Key Genes Regulating Skeletal Muscle Development and Growth in Farm Animals
}

\author{
Mohammadreza Mohammadabadi ${ }^{1}$ (D), Farhad Bordbar 1,*(D), Just Jensen ${ }^{2} \mathbb{D}$, Min Du $^{3}$ and Wei Guo ${ }^{4}$ \\ 1 Department of Animal Science, Faculty of Agriculture, Shahid Bahonar University of Kerman, \\ Kerman 77951, Iran; mrm@uk.ac.ir \\ 2 Center for Quantitative Genetics and Genomics, Aarhus University, 8210 Aarhus, Denmark; \\ just.jensen@qgg.au.dk \\ 3 Washington Center for Muscle Biology, Department of Animal Sciences, Washington State University, \\ Pullman, WA 99163, USA; min.du@Wsu.edu \\ 4 Muscle Biology and Animal Biologics, Animal and Dairy Science, University of Wisconsin-Madison, Madison, \\ WI 53558, USA; wguo2@wisc.edu \\ * Correspondence: farhadbordbar@agr.uk.ac.ir
}

Citation: Mohammadabadi, M.; Bordbar, F.; Jensen, J.; Du, M.; Guo, W. Key Genes Regulating Skeletal Muscle Development and Growth in Farm Animals. Animals 2021, 11, 835. https://doi.org/10.3390/ani11030835

Academic Editor: Zissis Mamuris

Received: 23 January 2021

Accepted: 12 March 2021

Published: 16 March 2021

Publisher's Note: MDPI stays neutral with regard to jurisdictional claims in published maps and institutional affiliations.

Copyright: (C) 2021 by the authors Licensee MDPI, Basel, Switzerland. This article is an open access article distributed under the terms and conditions of the Creative Commons Attribution (CC BY) license (https:// creativecommons.org/licenses/by/ $4.0 /)$.
Simple Summary: Skeletal muscle mass is an important economic trait, and muscle development and growth is a crucial factor to supply enough meat for human consumption. Thus, understanding (candidate) genes regulating skeletal muscle development is crucial for understanding molecular genetic regulation of muscle growth and can be benefit the meat industry toward the goal of increasing meat yields. During the past years, significant progress has been made for understanding these mechanisms, and thus, we decided to write a comprehensive review covering regulators and (candidate) genes crucial for muscle development and growth in farm animals. Detection of these genes and factors increases our understanding of muscle growth and development and is a great help for breeders to satisfy demands for meat production on a global scale.

Abstract: Farm-animal species play crucial roles in satisfying demands for meat on a global scale, and they are genetically being developed to enhance the efficiency of meat production. In particular, one of the important breeders' aims is to increase skeletal muscle growth in farm animals. The enhancement of muscle development and growth is crucial to meet consumers' demands regarding meat quality. Fetal skeletal muscle development involves myogenesis (with myoblast proliferation, differentiation, and fusion), fibrogenesis, and adipogenesis. Typically, myogenesis is regulated by a convoluted network of intrinsic and extrinsic factors monitored by myogenic regulatory factor genes in two or three phases, as well as genes that code for kinases. Marker-assisted selection relies on candidate genes related positively or negatively to muscle development and can be a strong supplement to classical selection strategies in farm animals. This comprehensive review covers important (candidate) genes that regulate muscle development and growth in farm animals (cattle, sheep, chicken, and pig). The identification of these genes is an important step toward the goal of increasing meat yields and improves meat quality.

Keywords: muscle development; myogenesis; adipogenesis; candidate gene; meat yield

\section{Introduction}

As a complex and heterogeneous tissue, skeletal muscle is considered a vital organ for the muscular system [1]. This very abundant tissue in vertebrates has different but crucial metabolic actions. Lean skeletal muscle mass regulates the body's rate of energy expenditure [2-4]. Theoretically, increased muscle mass and energy expenditure from muscle protein turnover can prevent obesity [5]. Moreover, skeletal muscle has the highest insulin-stimulated glucose uptake and thus maintains the insulin sensitivity of the whole body [6]. Elevated skeletal muscle development in farm animals is important because it 
creates tissue that meets human requirements for meat consumption. The development of fetal skeletal muscle involves primarily myogenesis, fibrogenesis, and adipogenesis [7] derived from mesenchymal stem cells (MSCs). Meat quality also can be enhanced by changing the $M S C$ commitment from muscle to adipocyte development through the provision of more intramuscular fat.

Skeletal muscle development is determined mainly by the proliferation and differentiation of myoblasts, which are precursors of muscle cells. Myogenic regulatory factors (MRFs) and growth promoters are crucial for muscle development in farm animals [8]. Generally, muscle growth, categorized as a heritable feature, can be modulated by fiber type position, especially with regard to metabolism and contractile speed, as well as temperature and food availability $[9,10]$. Skeletal muscle has a very unique ability to regenerate and remake itself in response to growth and injury, via the activation of muscle stem cells or satellite cells $[11,12]$.

\section{Myogenesis}

Myogenesis is the complex process of skeletal muscle construction in diverse species, including farm animals. Generally, the aim of myogenesis is the formation of multinucleated myofibers with contractile activity. The time required for each developmental phase varies among species [13]. Typically, myogenesis is regulated by the intricated networking of intrinsic and extrinsic factors [1], monitored by MRF genes in different phases as well as genes that code proteins called kinases [13]. Nutrition also plays an important role in the regulation of myogenesis. Malnutrition and overnutrition during gestation abated fetal myogenesis, but only overnutrition enhanced intermuscular fat accumulation $[14,15]$.

Prenatal muscle development is achieved by the proliferation and differentiation of myogenic factors; postnatal muscle growth is achieved by cascade actions of muscle satellite cells. The formation of muscle in farm animals is accomplished via various biological processes, including protein accretion and muscle cell proliferation [7]. Small proportions of progenitor cells in the myotome proliferate and then differentiate into myoblasts. These myoblasts withdraw from the cell cycle and begin to differentiate and fuse to each other to construct myotubes and primary myofibers [16]. Myoblasts near primary muscle fibers proliferate and fuse to form secondary muscle fibers [17]. Muscle fibers in adult animals are established primarily through secondary myogenesis.

In the late fetal stage, some myogenic cells become quiescent, leading to the formation of satellite cells. Thus, the number of myoblasts not only conditions the quantity of muscle fibers but also influences the amount of satellite cells present during postnatal growth [14]. As the number of muscle fibers does not change after birth in most cases, fetal myogenesis is critical for efficient muscle growth in farm animals [7]. Satellite cells first proliferate and then differentiate and fuse with existing muscle fibers, leading to postnatal growth in size or hypertrophy. Satellite cells in adult animal muscles remain quiescent unless activated by extrinsic stimuli (i.e., injury and exercise). Activated satellite cells repair or regenerate fibers in affected muscle. Some age-related diseases reduce the number of satellite cells leading to impaired regeneration and muscle degeneration [18].

\section{Effects of Transcription Factors and the Myogenic Kinome on Myogenesis}

Myogenesis is controlled mainly by specific muscle-related transcription factors, including MRFs (MYF5, MYOD, myogenin, and MRF4), PAX7, and PAX3. These factors act as terminal influencers of signaling procedures and contribute to proper development of each stage specific transcripts. Paired-box transcription factors are expressed first in mesoderm cells, followed by the expression of MYF5 and MYOD [19]. PAX3 expression is indispensable for skeletal muscle development; it upregulates the expression of $M Y O D$ during skeletal myogenesis. PAX7 keeps satellite cells quiescent and, along with the expression of MYF5, plays a critical role in the development of activated myoblasts $[13,20]$. Rehfeldt et al. [10] noted that MYOD and MYF5 are essential for the formation of muscle cell types, whereas myogenin and MRF4 are needed to stimulate differentiation and muscle fiber 
construction. MYF5, MYOD, and MRF4 are typically responsible for activating quiescent muscle stem cells and stimulating the genes required for muscle stem cell proliferation [12]. Moreover, these factors are required for myoblast differentiation and fusion into myotubes. $M Y O D$ is needed for the differentiation of activated myoblasts; together with myogenin and myocyte enhancer factor 2 (MEF2), it stimulates the process of differentiation [13]. Pownall and Emerson [21] reported that MYOD is able to stimulate other MRFs and thereby the expression of muscle-specific proteins in avian species.

The myoblast proliferation rate at $5-20 \mathrm{~h}$ in in vitro cultures was found to be greater in samples from 6-month-old Angus cattle than in those from Hereford and Wagyu $\times$ Angus cattle of the same age, and the expression of MYF5 was notably downregulated in Wagyu $\times$ Angus relative to Angus cattle [22]. The expression of PAX3, MYOD, and MRF4 in the pectoralis major muscle was greater in low-weight-select (LWS) chickens than in high-weight-select (HWS) chickens on the hatching day, and the expression of PAX3, PAX7, MYF5, MYOD1, MYOG, and MRF4 in this muscle was greater in HWS than in LWS animals at day 28 [23]. In the gastrocnemius muscle, the expression of PAX3, MYF5, $M Y O D$, and MYOG was greater in LWS than in HWS chickens on the hatching day, and the expression of PAX7, MYF5, MYOD1, and MRF4 was greater in HWS than in LWS birds at day 28 [23]. Quantitative real-time reverse-transcription polymerase chain reaction (qRT-PCR) analysis of samples from Dzhalginsky Merino sheep showed that MYOD1 was among 17 of 48 evaluated genes with the greatest expression in the loin muscle [24]. MYF5, another important regulator of myogenesis, was shown to be associated with traits related to meat quality in cattle [25] and pigs [26]. Several regulatory transcription factors, such as MYOD1, were identified in the biceps femoris and longissimus dorsi muscles (LDMs) of purebred (IB) and Duroc-crossbred $(\mathrm{IB} \times \mathrm{DU})$ pigs; MYOD1 was expressed in two developmental stages (birth and growth) and thus can crucially impact phenotypes [27]. For this reason, it must be considered an important candidate gene for muscle growth in pigs.

Myogenesis is not regulated solely by muscle-related transcription factors, which contribute to complex signaling cascades that precipitate the process. Protein kinases, which form a family of enzymes, modify the actions of target proteins via basic and reversible phosphorylation, a fundamental part of myogenesis. Many protein kinases have been shown to participate in different stages of myogenesis; thus, their activation or inhibition can directly affect muscle cell behavior [13]. Protein kinase A $(P K A)$ is required in different muscle developmental stages and is indispensable for the construction of myogenic precursors in the dermomyotome; its involvement leads to myotome construction by myogenic factors, such as PAX3, MYOD, and MYF5, in dermomyotome cells [28]. This activity is initiated with the involvement of Wnt1 and Wnt7a, produced by dorsal neural tubes outside the ectoderm. The upregulation and downregulation of $(\mathrm{Wnt}) / \beta$-catenin cascade signaling control myogenesis and adipogenesis, respectively [7]. PKA stimulates proliferation by promoting the expression of myogenic factors, including MYF5, MYOD, and PAX3, and suppressing the activity of $M E F 2$ via phosphorylation [13]. Cyclin-dependent kinases 2 and $4(C D K 2,4)$ control cell-cycle progression via the phosphorylation of retinoblastoma protein $(R b)$, which prevents $R b$ from binding the E2 factor $(E 2 F)$, thereby allowing continued expression of cell-cycle-related genes. In addition, phosphorylated $R b$ cannot bind $M Y O D$, which triggers $S$ phase entry, allowing for the suppression of differentiation by $C D K 2$ and $C D K 4[29,30]$. Extracellular signal-regulated kinase $(E R K)$ activation depends on the availability of growth factors $(G F s)$, including fibroblast growth factor (FGF) and insulin-like growth factor (IGF). In early myogenesis, ERK1/2 activation is crucial for myoblast proliferation and the suppression of myoblast differentiation; in late myogenesis, it is required for proper myocyte fusion [13]. Akt1 also supports proliferation by phosphorylating FOXO1, which suppress the expression of genes associated with cell-cycle exit, including $p 27$. $p 38 a$ has been shown to be important for the differentiation of many cell types [31-33]. In myogenesis, it causes myogenic precursor cells to exit the cell cycle via the phosphorylation of MEF2 and E47. All of these factors together, in association with MYOD 
and phosphorylated RNA polymerase II, activated by CDK9, trigger differentiation. Many studies have demonstrated the role of $A k t$ activity in the stimulation of differentiation and hypertrophy in culture and in vivo [34-37]. Specifically, Akt1 seems to be crucial for myoblast proliferation but not necessary for differentiation; it inhibits differentiation when its involvement occurs alone [38,39]. Elevation of the $A k t 2$ level is indispensable for differentiation [38], but $A k t 2$ activation is not necessary for proliferation. The inactivation of GSK3 $\beta$ in response to the $A k t$ level also contributes to differentiation; activated GSK3 $\beta$ suppresses myoblast differentiation and fusion [40-42] via the phosphorylation of NFATC3 and $\beta$-catenin. Akt is also responsible for the maintenance of GSK3 $\beta$ inactivation via its phosphorylation during hypertrophy [42,43]. The mammalian target of rapamycin (mTOR) is required for differentiation and hypertrophy [44], but its kinase activity is just demanded for hypertrophy $[45,46]$. mTOR and its substrate $S 6 K$, whose involvement is crucial during hypertrophy, induce protein synthesis by commencing cap-dependent transfer [13]. mTOR also upregulates microRNA-1 (miR-1), suppressing HDAC4 expression and upregulating important myogenic genes, such as the profusion protein follistatin [47]. Figure 1 illustrates the involvement of myogenic transcription factors and protein kinases in the regulation of different stages of myogenesis.

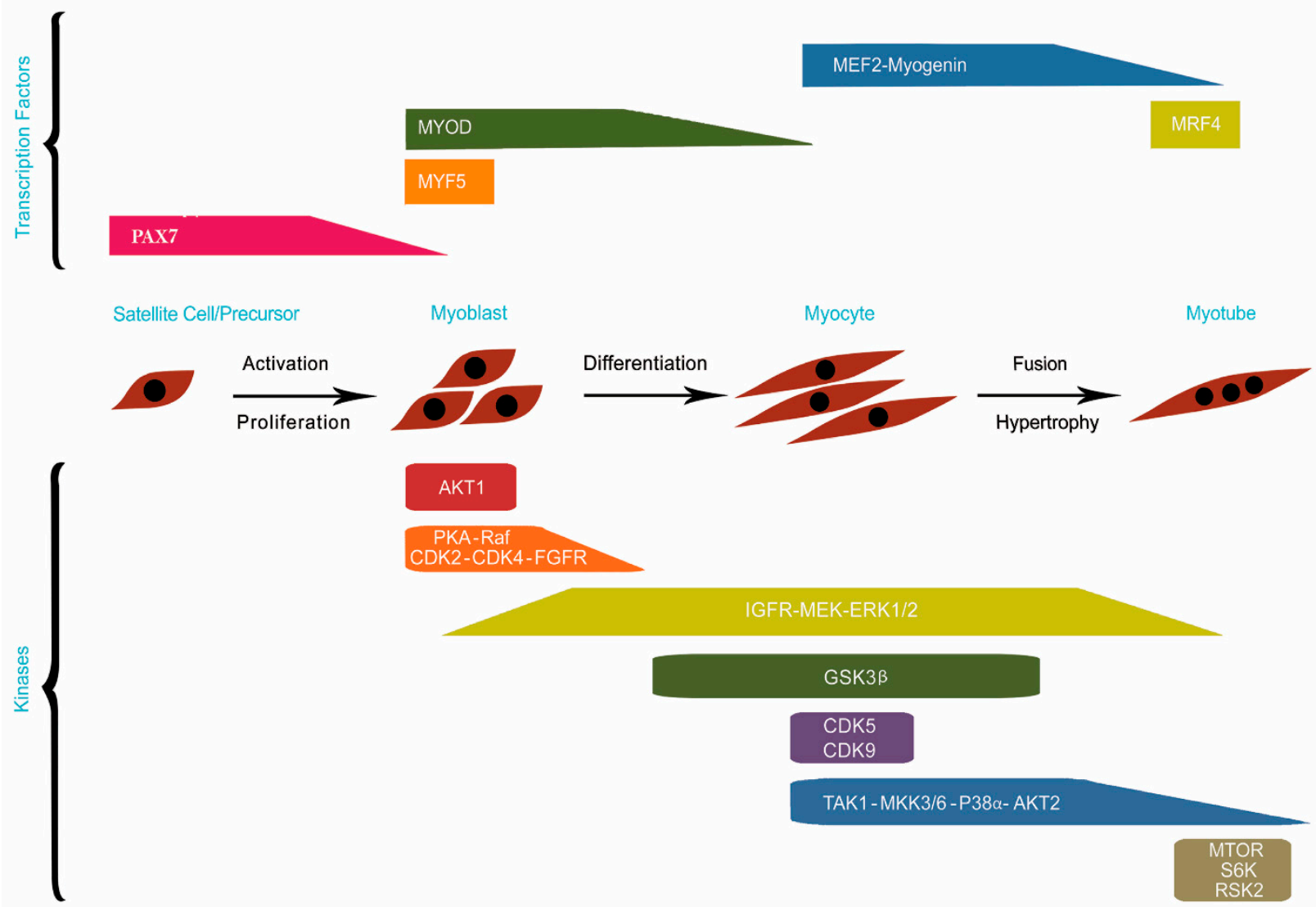

Figure 1. The involvement of myogenic transcription factors and protein kinases in the regulation of different stages of myogenesis. Embryonic precursors or quiescent satellite cells proliferate and construct myoblasts. Myoblasts then undergo differentiation to form myocytes. Finally, multinucleated myotubes are formed as a result of fusion of myocytes. The upper and lower sections of the figure illustrate transcription factors and protein kinases required for myogenesis, respectively (modified from [13]).

\section{Adipogenesis and Participating Transcription Factors}

The fundamental components of skeletal muscle are myocytes, adipocytes, and fibroblasts. Adipocytes are derived from adipogenic progenitors [48,49], produced mainly in 
the fetal period. The transcriptional factors that control adipogenesis include $C / E B P$ and members of the PPAR family. PPAR $\alpha, \gamma$, and $\delta / \beta$ are nuclear hormone receptor-regulating genes associated with lipid metabolism [50]. PPAR $\alpha$, which is expressed abundantly in striated muscle, has been recognized as a mediator that stimulates peroxisomal proliferation in rodent livers [50]. Its activation enhances fatty acid $\beta$-oxidation in muscle and leads to body weight reduction [51]. Relative to $P P A R \alpha, P P A R \gamma$ is expressed more strongly in adipose tissues [50], stimulating adipocyte differentiation [52,53]. PPAR $\delta$ is expressed abundantly in skeletal muscle, heart, and adipose tissue. Its active form enhances fatty acid oxidation in adipose tissue and muscle [54] and is upregulated in skeletal muscle during starvation [55]. During early adipogenesis, C/EBP $\alpha$ is stimulated and binds to the PPAR $\gamma$ promoter, stimulating its expression [56]. C/EBP $\alpha$ and $P P A R \gamma$ each induce the other's expression in a self-reinforcing regulatory loop [7] (Figure 2) and are required for terminal adipocyte differentiation via the stimulation of genes such as adipocyte protein 2 (AP2), lipoprotein lipase $(L P L)$, cluster of differentiation $36(C D 36)$, and glucose transporter type 4 (GLUT4) [57]. In bovine fetuses, myogenesis was found to be spoiled by proliferative preadipocyte-conditioned media, as demonstrated by the reduction of the fusion index, and enhanced by an adipocyte-conditioned medium, as demonstrated by the expansion of the myotube area [58]. Such crosstalk is regulated partly by adipokines, including leptin [59].

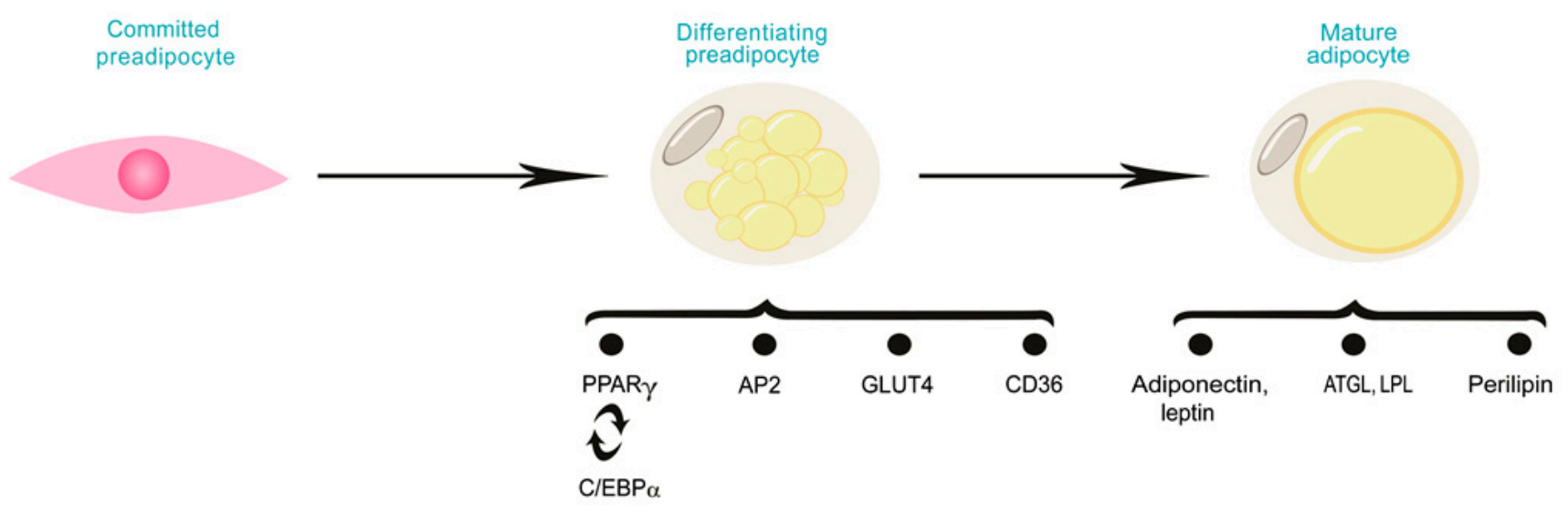

Adipogenesis

Figure 2. Overview of key factors involved in adipogenesis. Committed preadipocyte encounters growth arrest which leads to the formation of differentiating preadipocyte. Subsequently, differentiation occurs, and a mature adipocyte is formed.

\section{The Role of GFs in Skeletal Muscle Growth}

Diverse types of GFs affect the differentiation and proliferation of skeletal muscle growth. Hepatocyte growth factor (HGF) induces the proliferation and migration of myogenic cells [60] and was found to increase the surface elasticity of bovine satellite cells in vitro [61]. FGF2 was found to promote the proliferation of muscle precursor cells, including satellite cells and myoblasts, and to suppress cell differentiation in chickens [62]. Thus, the proper construction of muscle fibers in the embryonic period requires FGF2 expression. However, this factor also inhibits myogenesis by suppressing myogenin transcription, which is required for proper myotube formation [63]. IGFs regulate and promote cell proliferation, differentiation, and hypertrophy and protein synthesis during myogenesis $[13,64]$.

Transforming growth factor (TGF) $\beta$ and myostatin (GDF-8) have the opposite effect on differentiation [65]; thus, their expression must be limited in farm animals bred for meat. In chicken muscle, the expression of IGF-1 mRNA decreased during embryogenesis, increased after hatching, and decreased again after day 7 post-hatching, and was much greater in embryonic muscle than in embryonic liver [66]. In porcine satellite cells, IGF-I 
and IGF-II were upregulated during differentiation [67]. In fetal sheep, IGF-II mRNA was upregulated most at gestational day 85 , demonstrating its importance during this period of differentiation and myogenic fiber formation in the leg [68]. A delay in IGF-II expression and mutation of the MSTN gene led to an increase in the number of muscle fibers in double-muscled (DM) cattle [69]. Growth hormone $(G H)$ is another important factor; a major mechanism that (genetically and environmentally) affects skeletal muscle development in farm animals involves the GH-IGF axis [10].

\section{Candidate Genes Affecting Muscle Development in Cattle}

Beef production has been improved dramatically, but researchers still struggle to find quantitative trait loci (QTLs) and candidate genes affecting meat production and growth in cattle. QTLs and candidate genes related to muscle development are distributed over several bovine chromosomes (BTA), such as BTA2, 3, 4, 6, 20, and 29 [70-74]. Genome-wide association studies (GWASs) performed with high-density single-nucleotide polymorphism (SNP) arrays are the main means of detecting genetic variants explaining variation in such economically important traits.

Using next-generation sequencing (NGS) with nearly 12 million imputed SNPs, we identified several important candidate genes influencing hindquarter muscle development in Chinese Simmental beef cattle [74]; they included IQUB, NDUFA5, and ASB15 in a $\sim 322-\mathrm{kb}$ area on BTA4, and LMOD2 and WASL about $50 \mathrm{~kb}$ upstream of ASB15. ASB15, a conserved gene that is usually expressed in hypertrophied skeletal muscles [75], was found to stimulate protein turnover and synthesis, thereby inducing muscle precursor cell differentiation and muscle cell development $[75,76]$. NDUFA5 upregulation has been observed in various tissues, including skeletal muscle [77], and is associated with marbling scores in Hanwoo cattle [78]. IQUB knockdown can suppress the expression of c-myc, which is involved in myoblast proliferation and differentiation [79]. LMOD2 was found to be involved in the regulation of the length of thin filaments in muscle, and thus in muscle development in cattle [80]. WASL was reported to affect the cytoskeleton, a sophisticated network that plays a role in muscle contraction [81]. Based on such compelling evidence, we hypothesized that the $280 \mathrm{~kb}$ region in which all of these genes are located strongly influenced muscle development on BTA4 in beef cattle [74]. Using imputed NGS dataset (Illumina Hiseq 2500), we identified myotrophin $(M T P N)$ as a promising candidate gene affecting net meat weight [82]. This gene stimulated six markers that regulate muscle differentiation ( $M y o D, M y o G, M Y H 1, M Y H 2, M Y H 3$, and $M Y H 4)$, induced myotube hypertrophy by expanding myotube diameters, and reduced myoblast proliferation in flow cytometry and cell viability experiments [82]. MTPN has also been shown to affect muscle development in other species, such as pig [83]. MTPN and IGF-I have been shown to induce muscle cell hypertrophy by increasing myotube diameters in chickens [84]. Using the Illumina bovine SNP50 beadchip, Kim et al. [85] identified a marker of eye muscle area (EMA) on the DVL1 gene. Although the function of this gene in cattle is not known, research has shown that it is related to muscle development in humans and mice [86,87]. Thus, it was nominated as a candidate-gene-regulating muscle development in cattle [85]. qRT-PCR analysis showed that the expression of NCAPG, LCORL, and DCAF16 was upregulated in the fetal relative to the adult longissimus muscle in Chinese Qichuan beef cattle, reflecting the crucial roles of these genes in early bovine muscle growth [88]. NCAPG was also reported to be in linkage disequilibrium with the average daily gain (ADG) in cattle [89]. Candidate genes for muscle development and growth identified in Simmental beef cattle include MYH10 (associated with yearling weight), RLF (associated with ADG from birth to yearling), SQOR and ARHGAP31 (associated with body weight at the age of 18 months), and $T B C B$ (associated with birth weight) [90]. TBCB was identified as a candidate gene affecting meat quality in pigs because it is associated with actin and cytoskeleton filament development [91]. RLF has also been reported to markedly enhance DNA methylation of factors associated with transcriptional regulation, which is indispensable for embryonic muscle growth [92]. Mutations in the myostatin gene were found to lead to muscularity 
in DM cattle, causing about $20 \%$ more hypertrophy and about $50 \%$ less fat accumulation compared with normal cattle [93]. Among adipose-specific genes, FABP4 is a promising candidate related to intermuscular fat accumulation [94]; many important differentiation-, hormone-, and fat-related regulatory factors have been identified in its promoter region. RAI14 and ZNF423 have also been reported to be involved in adipogenesis in bovine muscle $[95,96]$. cDNA microarray examination of gene expression profiles in fetal bovine longissimus muscle led to the identification of FSTL1 and IGFBP5 as important genes related to muscle development [97]. These genes have also been shown to be associated with MYOD expression in a mouse model [98].

The identification of candidate genes associated with growth is also important because these genes are potentially related to muscle development. BTA14 harbors several crucial candidate genes associated with growth, including RPL39, PLAG1, RGS20, FAM110B, TOX, RP1, TCEA1, UBXN2B, and MRPL15 [99]. Using a high-density SNP array, Zhang et al. [100] showed that the PLAG1-OXR1 region on BTA14 is a candidate region affecting meat yield from Wagyu cattle. OXR1 has also been reported to regulate muscle development [101]. Its expression is regulated by the FABP5 gene through the PPARG node. A GWAS led to the recognition of $R A B 28, B T G 1$, and SMN1 as candidate genes for muscle development in Brahman cattle [102]. RAB28 is involved in the proliferation of endothelial and smooth muscle cells [103]. BTG1 seems to be involved in myogenic induction [104,105], and it regulates myoblast differentiation. SMN1, located on BTA20:8Mb, is associated with murine skeletal muscle growth [106]. Overall, the identification of candidate genes related to muscle development can be very beneficial for the beef industry, as it provides opportunities for the enhancement of meat production.

\section{Candidate Genes Affecting Muscle Development in Sheep}

An important goal of sheep breeders is to gain an understanding of the regulation of muscle growth and development, with the ultimate aim of increasing muscle growth. Recently, much research has focused on economically important traits and candidate genes influencing meat production from sheep, particularly those related to muscle development.

The most comprehensively studied QTLs in sheep are related to muscle hypertrophy. The paternal heterozygous callipyge mutation leads to skeletal muscle hypertrophy, especially in the hindquarters [107]. The callipyge variant is related to an SNPCLPG mutation in the intergenic region between DLK1 and GTL2 on ovine chromosome 18 (OAR18), which contains various paternally expressed genes, such as BEGAIN [108], DLK1 [109], PEG11 or RTL1 [110], and DIO3 [111]. It also contains several maternally expressed noncoding RNA genes, including antiPEG11 [110], GTL2 [112], MIRG [113], and MEG8 [110]. Dlk1 is a potent candidate gene with the potential to generate muscle hypertrophy in callipyge sheep; Dlk1 mRNA expression was increased markedly in the muscles of these sheep from day 120 in gestation day to 84 days after birth [107]. The rib-eye muscle (Carwell) locus, which is in close proximity to CLPG on OAR18, has been associated with muscular hypertrophy but only of the LDM; it has no effect on carcass fatness [114]. The Carwell phenotype has been reported to enhance the loin eye area by about 11\% and LDM weight by about 7\% [115]. In comparison with the callipyge phenotype, the Carwell phenotype has no impact on meat quality, including meat hardness and intramuscular fat content [116]. The MSTN gene, which encodes myostatin, plays an important role in muscle development in sheep. In Texel sheep (known for double muscling), a mutation on MSTN producing a novel binding site for mRNA molecules was found to lead to muscle hypertrophy [117]; this mutation was shown to affect the meat and fat contents in lamb carcasses [118]. Gan et al. [119] identified various mutations in several regions of this gene that correlated directly with the ADG and indirectly with the double-muscling phenotype and myostatin gene function. MSTN is also believed to be related to calpastatin (CAST) expression and lamb meat quality $[120,121]$. In turn, CAST gene function is associated with protein activity in muscle and the proportion of postmortem tenderization [121-123]. Nikmard et al. [124] reported that CAST is associated with muscle mass enhancement in sheep. 
The $M E F 2 B$ gene is a member of the myocyte enhancer factor- 2 family, which also includes $M E F 2 A, M E F 2 C$, and $M E F 2 D$. MEF2B regulates muscle growth and development in sheep; PCR experiments have revealed variants in this gene that affect sheep growth and body weight $[125,126]$. GWASs led to the identification of several genes, including complex subunit 1 (MSL1), POL, and shisa family member 9 (SHISA 9), as candidate genes affecting the regulation of processes such as cell growth and muscle differentiation [125,127]. Zhang et al. [127] identified five variants in or near MEF2B, RFXANK, RIPK2, GRM1, POL, and $U B R 2$ with roles in growth and meat production. They also reported the downregulation of TRAF6 in myoblasts, suggesting that this gene plays roles in myoblast proliferation and differentiation in sheep. Lamb carrying the $F e c B$ gene in a backcross population of Texel sheep exhibited a difference in meat color and greater dressing percentage and eye-muscle depth than did noncarriers [128]. Skeletal muscle transcriptome analysis revealed candidate genes affecting muscle development in Bandur sheep; genes of the Kelch superfamily (KLHL6, KLHL34, and KLHL40) were upregulated more than two-fold, and ANKRD2 and KLH13 were found to be involved in muscle development [129]. Based on analysis of gene expression profiles in ovine skeletal muscle from five Spanish meat breeds, candidate genes related to muscle contraction, including actin $\alpha 1$ (ACTA1), myosin light chain phosphorylatable fast skeletal muscle (MYLPF), myosin heavy chains 2 (MYH2) and 7 (MYH7), tropomyosin 2 (TPM2), and titin (TTN), were identified [130]. Fan et al. [131] employed whole-genome bisulfite sequencing to examine genome-wide DNA methylation profiles in $\mathrm{Hu}$ sheep and identified many important differentially methylated genes associated with muscle growth and metabolism (Figure 3). Based on network analysis, they identified nine candidate genes (ADIPOQ, CCNA2, ITGA2, MYOG, MAPT, DIAPH1, NR4A1, DLK1, and $C O L 1 A 2)$ that may be associated with muscle cell proliferation and differentiation and determined that their regulation across DNA methylation can control differential muscle development. In Icelandic sheep, Guðmundsdóttir [132] identified several candidate genes for muscle growth and development (CSF3R, ADAM17, GADD45B, GRID2, SPG11, DAB2, FREM3, GAB1, KLF13, AKAP6, PNN, DOCK1, and TRRAP) near the most closely associated SNPs. Flicek et al. [133] also reported many genes associated with muscle growth and development and muscle fiber development in sheep [USMG5 (Chr 13), IFRD1 (Chr 4), MSC (Chr 9), PPP2R3A (Chr 1), PITX1 (Chr 5), TCF21 (Chr 8), CACNA1S (Chr 12), PITX2 (Chr 6), MYOG (Chr 12), and MYOD1 (Chr 15)]. A comprehensive analysis of genomewide DNA methylation in the LDMs of Dorper $\times$ small-tailed Han and small-tailed Han sheep revealed candidate genes potentially associated with muscle production and growth (ACOX2, PPARG2, NTN1, RIN2, MAPRE1, ACSL1, SH3PXD2B, ADAMTS2, MYOM1, ZDHHC13, TGFB3, and RYR1) [134]. Various mutations in the leptin gene associated with muscle growth, meat quality, and carcass fat content have been identified in sheep $[135,136]$. The FABP4 gene has an important effect on meat quality in sheep, as it does in cattle; polymorphism of this gene affects the marbling, shear force, and intramuscular fat content of the LMD [116]. In addition, FABP4 allele A promotes lamb meat tenderness [137]. 


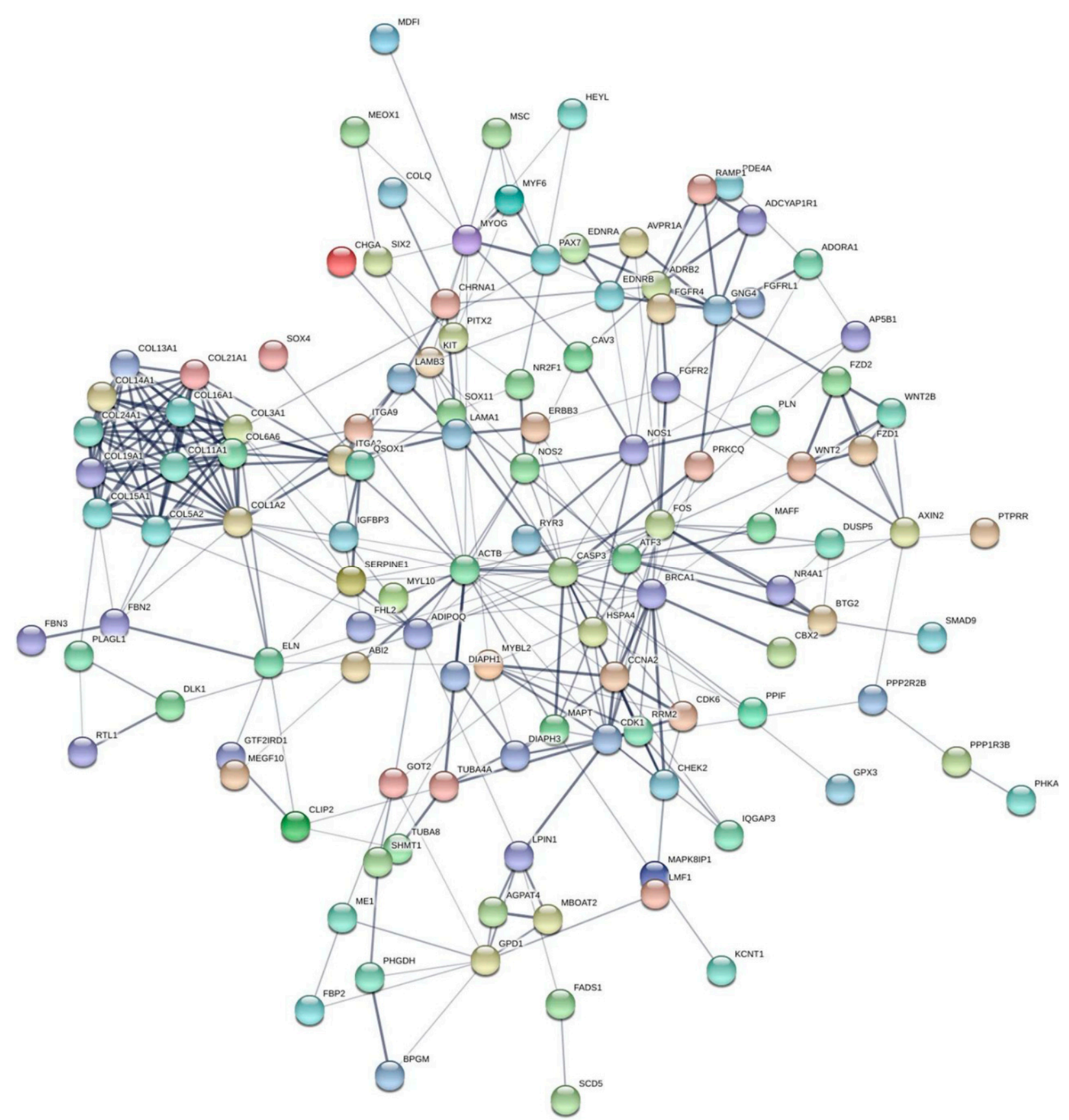

Figure 3. The network of differentially methylated genes associated with muscle development in sheep. Darker lines indicate higher confidence levels [131].

\section{Candidate Genes Affecting Muscle Development in Pigs}

Many researchers have examined pig muscle characteristics (e.g., growth and development) in efforts to improve quantity and quality of pig meat and pig growth rates. The identification of additional candidate genes would aid understanding of the mechanisms underlying pig muscle growth, benefitting breeders and consumers and contributing to the improvement of efficiency in the pork industry.

Gene expression changes dramatically throughout the pig life cycle, particularly during prenatal growth and in the first stages of postnatal growth $[138,139]$. For example, ACTC1, DLK1, COMP, ARHGAP36, FGF21, TNN, IBSP, and ATP6V0D2, which are related to the development of various tissues, including muscle, are markedly upregulated in newborn piglets [27]. In addition, the RETN gene, which is associated with lipogenesis and thus 
meat quality, was found to be upregulated at birth [27]. Ayuso et al. [27] identified several candidate genes that might regulate muscle growth and development in IB and IB $\times$ DU pigs (MEFs, SIM1, TCF7L2 or FOXO1, KLF1 or IRF2, MYH10, PVALB, CTNNB, MYOG, and SOX4). Comparison of the muscle transcriptomes of piglet [140] and weanling [141] IB and IB $\times$ DU pigs revealed that MYH10 is upregulated in IB $\times$ DU pigs, proving its association with muscle development. Ayuso et al. [27] also identified candidate genes associated with protein degradation and turnover and thus related to muscle development (CTSF, ADAMTS8 or CELA2, HSPS1, HSPA4L, ELANE, MMP9, FBXO32, and DNAJA1). Among 83 genes found to be upregulated in LDM in their research, ZIC1 and MMP13 control myogenesis and myostatin signaling [142-145]. Using Solexa/Illumina's genome analyzer in Lantang (LT, obese) and Landrace (LR, lean) pig breeds, Zhao et al. [138] identified 595 differentially expressed myogenesis genes (Figure 4). Moreover, they identified that $I K B K B$, ACVR1, GSK3B, STMN1, and ITGA might cause more muscle fibers in LR compared to LT. In comparison with LR, LT showed higher expression of several important inhibitors of myogenesis including HMOX1, NOTCH2, CTNNA1, ID1, ID2, SMAD4, GPC3, MSTN, and $C A B I N 1$, which might lead to slowing down the process of muscle differentiation in LT than in LR.

Genes related to an increased number of muscle fibers and the regulation of late myogenesis (STMN1, ACVR1, GSK3B, IKBKB, and ITGA) were identified in the Landrace breed [146]. In an RNA-sequencing analysis focusing on myogenesis phases in 40-, 55-, 63-, 70-, and 90-day Tongcheng and Yorkshire pig fetuses, Liu et al. [147] identified candidate genes associated with muscle growth and responsible for developmental differences between the breeds (PPP1CC, EP300, MYO9A, PTEN, CDK14, and IRS1). The Akirin2 gene has been reported to be a promising candidate gene affecting porcine muscle satellite cell proliferation and differentiation, acting via the ERK1/2 and NFATc1 signaling pathways [148]. The LEF1 gene, which is associated with the Wnt signaling pathway, plays an indispensable role in muscle fiber development by regulating the expression of MRFs such as MYF5 and MYOD. Reis et al. [149] recognized LEF1 as a promising candidate gene whose differential expression affects muscle mass; they observed greater expression of this gene in 3-week-old and 40-day-old fetuses of Duroc $\times$ Landrace $\times$ Large White cross pigs than in Piau pigs, associated with somite construction and proliferation and myoblast fusion. Notch genes (Notch1-4) have different expression patterns during prenatal and postnatal tissue development in mammals. Notch1, but not Notch2 or Notch3, plays a key role in porcine satellite cell function, regulating the expression of the HES5 gene, which controls MYOD and MYOG expression. Notch 1 also controls GSK3 $\beta-3$ gene expression, which has an important role in the Wnt signaling pathway [146,150]. Li et al. [151] examined the systematic correlation between obesity and DNA methylation and generated gene expression maps for muscle and adipose tissue. They identified favorable expression of ACE, PRKAR1A, PRKCQ, and GHSR in muscles; these genes stimulate the release of growth hormone and increase lean mass in obese pigs [152]. In Berkshire pigs, the hydroxysteroid 17-beta dehydrogenase 4 gene may influence muscle development, and it has been found to play a key role during early myogenesis, when its mRNA expression is substantially elevated [153]. Some genetic mutations have major impacts on muscle fiber number and size in pigs; many are related to muscle hypertrophy and in some situations affect meat quality [154]. A mutation in the RYR1 gene causes lean muscle growth and muscle hypertrophy in heterozygous pigs [132]. Mutations in the IGF2 and PRKAG3 genes result in enhanced muscle mass in pigs [155]. Analysis of the LDM transcriptomes from Iberian pigs with divergent intramuscular fat content led to the identification of several candidate genes related to skeletal muscle development (FOSB, FOS, CHAC1, ATF3, PPP1R15A, JUNB, DUSP1, PPP1R1B, NR4A2, CYRS1, EGR1, EGR2, EGR3, and POU3F1) [156]. Moreover, Muñoz et al. [156] established 18 gene networks; network 1 contained many genes associated with skeletal and muscular system development (ACTC1, ASB10, AHSP, ARHGEF4, ARHGEF6, DMD, JUNB, LMO7, MYL12A, RPRM, SDR16C5, SIRT3, and UCK2). Analyses of regulatory impact factors led to the identification of genes associated with adipogenesis (ARID5B, CREB1, VDR, ATF6, and 
SP1) and myogenesis (KLF11 and MYF6) [156]. In an analysis of the pig LDM transcriptome, Lobjois et al. [157] identified candidate genes in different functional networks: cell proliferation and myogenic differentiation (AK1, BAG3, BNIP3, CDC34, CKM, COL1A2, CSNK2B, DES, FKBP8, GSN, HSP90AA1, IGF2, SET, TNNC2, and TNNT3), and energy metabolism and muscle development (COX8, DYSF, EEF2, IPO13, MYOZ1, NEB, TPM1, TTN, H19, NOP17, and RPL13A). MYH7, MYL1, and MYL3, associated with muscle development, were also identified via transcriptome analysis in pig. Using RNA sequencing in combination with other livestock genomics research, Guo et al. [158] mentioned SFRP2, $K D M 6 A$, and OGT as candidate genes associated with pig growth traits. SFRP2 has been shown to play key roles in muscle development and muscle satellite cell proliferation and differentiation in mice $[159,160]$, and to affect skeletal muscle development during embryogenesis in pigs [158]. RNA sequencing led to the identification of ASB2, MSTN, $A N K R D 1$, and $A N K R D 2$ as functional candidate genes associated with skeletal muscle development in Wei and Yorkshire pigs [161]. MSTN expression was found to be lesser in Wei pigs than in Yorkshire pigs, suggesting that this gene inhibits muscle growth less in the former breed [161]. ASB2, which has a negative regulatory effect on muscle mass [162], was also found to not be conductive to muscle growth in Wei pigs [161]. ANKRD1 and $A N K R D 2$ belong to the muscle ankyrin repeat protein family and are known to regulate skeletal muscle cell differentiation [163]. To elucidate the genetic background affecting meat content, Ropka-Molik et al. [164] used microRNA expression profiles to identify DEGs that were upregulated and downregulated in pigs with greater muscle mass. They identified the SOX2, SIRT1, KLF4, PAX6, and transforming growth factor-beta genes as candidates likely associated with muscle mass, and found that SETD2, which encodes a histone methyltransferase, had modified transcript levels determined by loin mass. This gene is associated with epigenetic mechanisms controlling myoblast proliferation and differentiation, and its silencing results in cell-cycle arrest [165]. Taken together, the functions of this gene are crucial for muscle development and growth in pigs. In addition, the TBX2 gene, which encodes the T-box transcription factor, is upregulated in pigs with greater muscle mass (Figure 5). TBX2 controls the cell cycle in skeletal muscle through interaction with MYOD and cell-cycle regulators, including $p 21$ and $p 14$ [166]. 


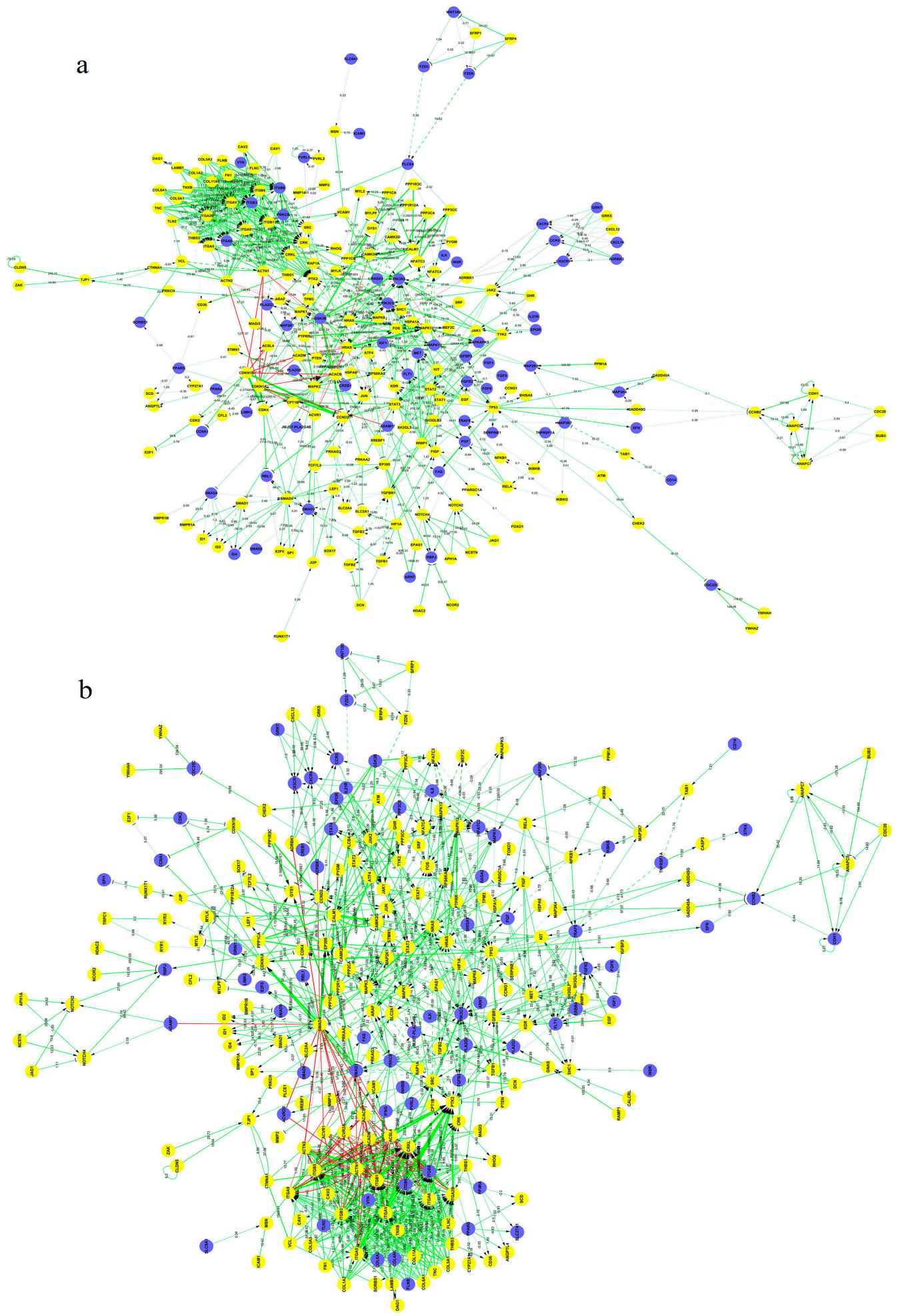

Figure 4. The interaction network of differentially expressed genes (DEGs) regulating myogenesis in Landrace (LR) (a) and Lantang (LT) (b) pig breeds. Yellow and blue dots represent DE and non-DE genes, respectively. Straight lines represent interaction association between genes. Solid and dashed lines represent direct and indirect interaction, respectively. Value and diameter of lines represent the interaction size [138]. 


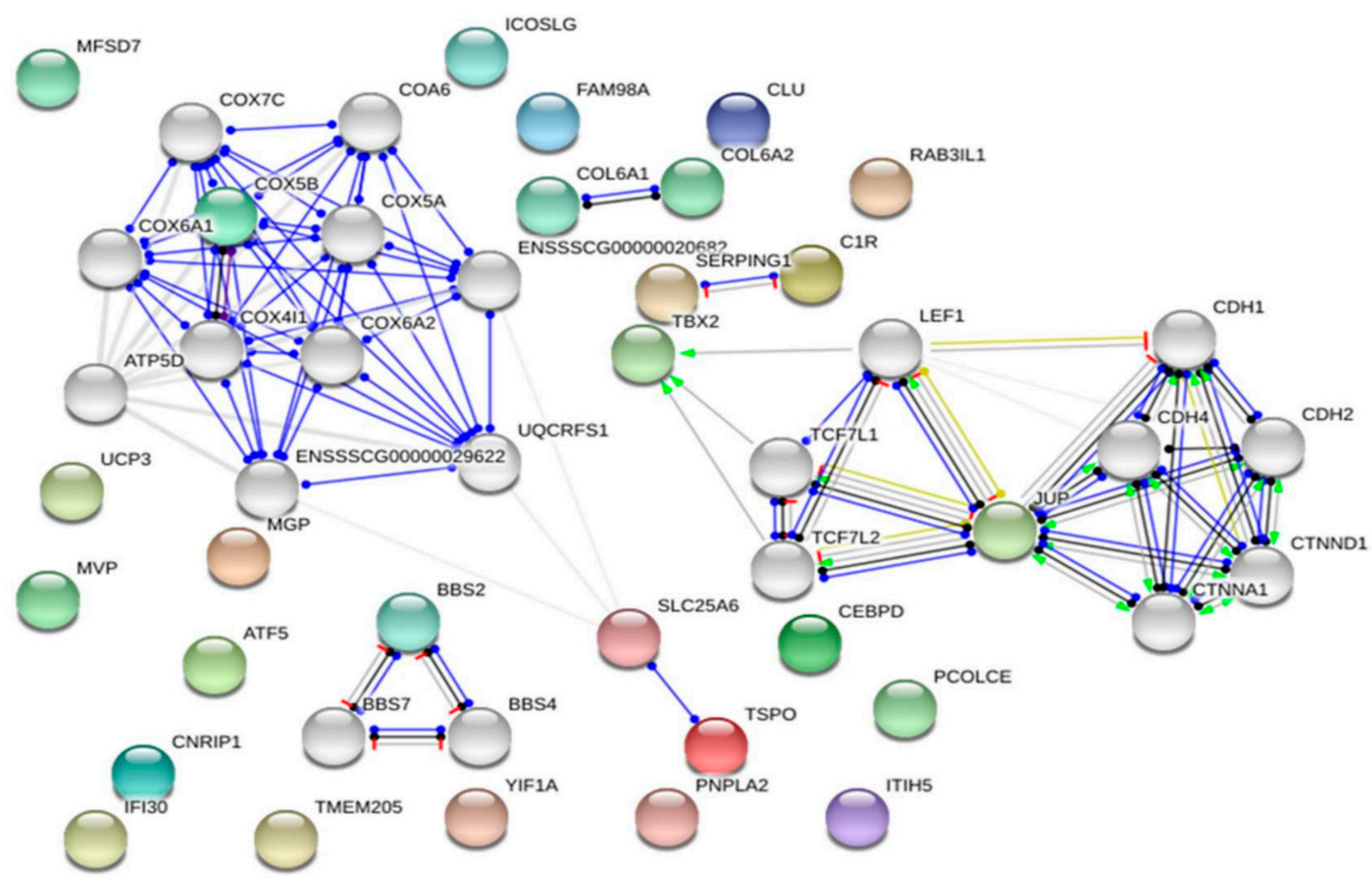

Figure 5. Upregulation of differentially expressed genes in the muscle of pigs with greater-than-normal muscle mass. Identified genes were colored and marked in grey; line shape represents anticipated mode of action. Lines colored represent anticipated mode of action (red shows interactions that were experimentally identified; blue shows interactions from selected databases; black shows coexpression; green shows text-mining relations and interactions contingent on appropriate researches stating a transfer from different organisms; and yellow shows transcriptional adjustment [164].

\section{Candidate Genes Affecting Muscle Development in Chickens}

The consistently increasing demand for poultry meat has stimulated breeding of chickens with greater production value [167]. Controlled selection is performed to enhance the growth rate, feed efficiency, and carcass meat content of chicken [168]. Chicken muscularity and muscle growth are economically important characteristics with substantial agricultural implications. Thus, selection for chickens with increased muscle mass and acceptable meat quality is important to achieve consumer satisfaction. An understanding of the mechanisms underlying muscle development and growth and the identification of related candidate genes are key for efficient selection for poultry production.

Chickens bred for meat (broilers) and egg production (layers) are used in the bestknown models for the investigation of the mechanisms underlying the regulation of the myogenesis rate and muscle development. In past decades, selection has focused primarily on the improvement of the broiler growth rate and muscle mass. Zheng et al. [169] examined gene expression differences in muscle between layers and broilers by microarray hybridization, and identified several genes associated positively or negatively with growth rates (and thus likely involved in muscle growth and development). They determined that the slow growth rate of layers relative to that of broilers was related to the higher expression levels of slow-type muscle-related genes (MB, MYH7B, TNNI1, MYL3, and MYL2B) and identified DEGs associated with satellite cell proliferation and differentiation, as well as muscle hypertrophy (MUSTN1, FHL2, FGFR2, HS6ST2, and CSRP3; Table 1). CSRP3 was reported to be downregulated in humans with pathogenic cardiac hypertrophy [170]. FHL2 
expression in muscle precursor cells stimulated myoblast differentiation in mice [171], and it may control muscle growth and hypertrophy via the regulation of satellite cell proliferation and differentiation in chickens. The expression level of MUSTN1, a candidate gene related to muscle development that is upregulated after exercise in hypertrophic muscle [172], was greater in broilers than in layers, suggesting that this gene is a key regulator of skeletal muscle hypertrophy [169]. Broiler chickens also have lower expression levels of FBXO22, FBXO30, UCHL1, RNF12, HERC4, RLD5, and HERC5 than do layers; these genes are associated with protein degradation and may be responsible for the greater muscle mass of broilers compared with layers [169]. Zheng et al. [169] also reported that $D K K 3$ may be associated with muscle development in chickens, as it is expressed more in broilers than in layers, in accordance with the divergent muscle growth rates of the two chicken lines. DKK3 is known to suppress tumor growth by inhibiting cancer cell proliferation in human [173-175]. In another study, POMC, NMU, NPW, PMCH, GAL, and FOS were determined to be related to the broiler growth rate, as variable growth was attributed to their differential expression in the hypothalamus [176]. In a comprehensive study of DEGs that included principal component analysis, Nihashi et al. [177] identified 13 candidate genes potentially related to myoblast proliferation and differentiation in chickens (CDKN2B, ACTC1, MYH15, TNNI1, TNNI2, TNNT2, CCK, CXCL14, MDK, PENK, CSRP2, MFAP5, and UCHL1). These genes play crucial roles in muscle cell differentiation in chickens. CXCL14 knockdown stimulates myogenic differentiation through the suppression of the myoblast cell cycle in mice [178]. CSRP3 induces myoblast differentiation [179] and CSRP2 is associated with the differentiation of smooth muscle cells in chicken [180]. The CSRP2 expression level was high across differentiation in WL and UKC myogenic cells in chickens [177]. MFAP5 tended to be more upregulated in WL than in UKC myogenic cells, indicating that it inhibits myotube formation in chickens. The level of BMP4 expression in the hindlimbs of UKC broilers and WL layers was found to be highest at HamburgerHamilton (HH) stage 31-34 (E7-8) [181], suggesting that enhanced BMP4 expression has a breed-dependent effect on myofiber formation. Using RNA sequencing, Xue et al. [182] analyzed the transcriptomes of Jinghai Yellow chicken muscle tissues in different early developmental phases. Their functional analyses resulted in the identification of DEGs related mainly to muscle development and growth (GH, IGF2BP2, IGFBP3, CEBPB, FGF2, and IGFBP5); in total, 44 candidate genes (including FN1, MYH10, MAPK9, FGF2, CFL2, IRS1, PHKA1, FGF16, PHKG1 and PHKB) were related to differences in growth among developmental stages. They also identified genes associated with muscle differentiation and development (MYOD1, MYLK2, SMYD1, BTG2, ANKRD2, PPP3CA, GPX1, TCF15, KLHL40, and $C R Y A B)$. CEBPB is known to suppress myogenesis and activate adipogenesis $[183,184]$ and to control several genes in response to GH [185].

GWASs have been used to identify gene loci and genomic regions related to muscle development more robustly and consistently than other approaches [186]. A GWAS led to the identification of five SNPs in $1.5 \mathrm{Mb}$ of the KPNA3-FOXO1A region on GGA1 as related to muscle growth in an F2 resource chicken population [187]. Two of these SNPs were determined to affect the ADG, and the gene closest to them was recognized as FOXO1A [187], a crucial transcription factor for skeletal muscle development [188-190]. Several SNPs on GGA4 have been related significantly to chicken growth [191,192], and genes located close to them, such as LIM domain-binding 2, ligand-dependent nuclear receptor corepressor-like protein 1 , and microtubule-associated protein tau, are less upregulated in the breast muscle of slow-growing relative to fast-growing chickens, suggesting that they are associated with muscle development [192]. Another GWAS led to the recognition that a region on GGA3 was related to the breast muscle percentage and weight in chickens [193]. The GJA1 gene, located in this region, was identified as a candidate gene affecting muscle development, and its upregulation was found to be associated with increased breast muscle weight during development [193]. Several myogenic gene polymorphisms significantly related to muscle development (e.g., in IGF1R [194], IGFBP2 [195], IGF1 [196], GHR [197], PIT1 [198], GHSR [199], GHRL [200], MSTN [201], MEF2A [202], MYF5 [203], and PAX7 [204]) have 
been identified in chickens. We also identified polymorphism of UCP gene associated with growth traits in Mazandaran indigenous chicken [205]. UCP2 gene is expressed hugely in several tissues such as adipose and skeletal muscle in human [206]. Although there is a lack of information regarding the association of $U C P$ gene and muscle development in chicken, we hypothesized that this gene has potential to be associated with muscle growth in chicken.

Table 1. Genes associated with muscle growth in broiler and layer chickens.

\begin{tabular}{|c|c|c|c|c|c|c|}
\hline \multirow{2}{*}{ Gene Name } & \multirow{2}{*}{ Symbol } & \multicolumn{5}{|c|}{ Fold Change * } \\
\hline & & 1D & $2 \mathrm{~W}$ & $4 \mathrm{~W}$ & $6 \mathrm{~W}$ & $8 \mathrm{~W}$ \\
\hline \multicolumn{7}{|l|}{ Slow-type myofiber protein genes } \\
\hline Troponin I type 1 (skeletal, slow) & TNNI1 & -1.99 & 1.05 & -6.47 & -1.05 & 1.14 \\
\hline Myoglobin & $M B$ & 1.04 & -1.81 & -10.04 & -6.8 & 1.17 \\
\hline Myosin, light chain 3, alkali; ventricular, skeletal, slow & MYL3 & -1.96 & -1.04 & -19.79 & -1.41 & -1.02 \\
\hline Myosin, heavy chain 7B, cardiac muscle, beta & MYH7B & -3.07 & -1.01 & -11.31 & 1.1 & 1.36 \\
\hline Similar to myosin L2B regulatory light chain, cardiac muscle - chicken & LOC417506 & -1.27 & 1.04 & -58.02 & -5.54 & 1.34 \\
\hline Myelin basic protein & $M B P$ & 1.16 & -1.81 & -1.83 & -3.67 & -1.68 \\
\hline Similar to dynein light chain-2 & LOC417663 & -1.25 & -2.13 & -1.77 & -1.28 & -1.73 \\
\hline \multicolumn{7}{|l|}{ Satellite cell proliferation and muscle hypertrophy } \\
\hline Cysteine and glycine-rich protein 3 (cardiac LIM protein) & CSRP3 & -2.17 & 1.01 & -9.44 & -16.72 & -1.04 \\
\hline Four and a half LIM domains 2 & FHL2 & -1.38 & -8.19 & -10.95 & -7.65 & -9.84 \\
\hline Similar to actin binding LIM protein family member 2 & LOC422866 & -1.08 & -2.06 & -1.78 & -2.24 & -2.56 \\
\hline Fibroblast growth factor receptor 2 & FGFR2 & -1.31 & -2.28 & -1.05 & -1.6 & -1.87 \\
\hline Fibroblast growth factor 1 (acidic) & FGF1 & -1.11 & -2.45 & -2.07 & -2.75 & 1.61 \\
\hline Heparan sulfate 6-O-sulfotransferase 2 & HS6ST2 & -3.07 & -4.09 & -1.51 & -2.13 & -3.1 \\
\hline Musculoskeletal, embryonic nuclear protein 1 & MUSTN1 & -1.01 & 2.94 & 2.17 & 2.45 & 1.51 \\
\hline Fibroblast growth factor 16 & FGF16 & -1.06 & 2.86 & 2.45 & 8.16 & 2.77 \\
\hline Inner centromere protein antigens $135 / 155 \mathrm{kDa}$ & INCENP & 2.02 & 1.59 & 2.15 & 1.39 & 1.3 \\
\hline NudE nuclear distribution gene $\mathrm{E}$ homolog 1 (A. nidulans) & NDE1 & 1.49 & 2.48 & 2.68 & 1.91 & 1.23 \\
\hline
\end{tabular}

* Comparison of expression values between muscle cells of broilers and layers, which normalized to a fold change of 1.0 and -1.0 in case of broilers having more and less mRNAs, respectively. D stands for day and W stands for week [169].

Using high-throughput sequencing and microarray experiments, scientists have identified numerous candidate genes associated with skeletal muscle development in chickens. RNA sequencing of skeletal muscle samples from white rock and Xinghua chickens revealed greater expression of $F O X O 3$, which may suppress skeletal muscle development in the Xinghua breed; decreased FOXO3 expression may upregulate growth-related genes in DF-1 cells [207]. A comparison of DEGs between embryonic day 14 and week 7 in normal and sex-linked dwarf chickens led to the identification of numerous genes involved in the Wnt, insulin, MAPK, and PI3K-Akt pathways and associated with chicken muscle development; the interaction of these genes with miRNAs leads to the formation of regulatory (e.g., miRNA-mRNA) networks for skeletal muscle development [208].

Several miRNAs have been reported to have regulatory effects in different stages of muscle development. Integrative miRNA target prediction and network analysis led to the identification of many candidate genes and miRNA targets related to skeletal muscle development in chickens; for example, gga-miR-1a inhibits $A C V R 2 B$ gene expression, and $R E C K$ is the target of $g g a-m i R-200 b$ [169]. In another study, let-7b was found to inhibit GHR gene expression and thus to play an important role in skeletal muscle development in chickens [209]. The miR-206 gene was also found to play a critical role in chicken muscle development, with a proven effect on chicken birth weight [210]. In vitro experiments showed that miR-203 inhibits myoblast proliferation and differentiation in chickens through the suppression of c-JUN and MEF2C, respectively [211]. c-JUN and E2F1 play crucial roles in the stimulation of myoblast proliferation in chickens via the control of their target genes $[211,212]$. 


\title{
9. Conclusions
}

Muscle development is a complex but consistent process that can be improved substantially in farm animals through selection and be further enhanced by identification of related candidate genes. During the past years, significant progress has been made for understanding the mechanisms of muscle growth and development, and thus, we decided to write a comprehensive review covering regulators and (candidate) genes crucial for muscle development and growth in farm animals. We have highlighted important regulators including transcription factors, myogenic kinome, and GFs, and investigated the role of them on different aspects of muscle growth. Moreover, the role of many important (candidate) genes such as MTPN, IQUB, NDUFA5, ASB15, LMOD2, and WASL (beef cattle), differentially methylated genes (sheep, chicken), and the interaction network of DEGs (pig) on muscle growth in farm animals were discussed. Identification of such important regulators and genes offers enormous help for marker-assisted selection, plays an important role toward the goal of increasing meat yields, and helps breeders to maximize meat quantity and quality. In addition, the gene sets mentioned have the potential to be generally beneficial to the applied study of mammalian muscle growth. However, the mechanisms underlying muscle development and growth in farm animals especially beef and sheep need further explorations.

Author Contributions: Writing—original draft preparation and writing—review and editing, F.B.; validation and supervision, M.M.; conceptualization and project administration, M.D.; conceptualization and writing—-review and editing, W.G.; validation and writing—-review and editing, J.J. All authors have read and agreed to the published version of the manuscript.

Funding: This research received no external funding.

Institutional Review Board Statement: Not applicable.

Data Availability Statement: Not applicable.

Conflicts of Interest: The authors declare that they have no competing interests.

\begin{abstract}
Abbreviations
The following abbreviations are used in this manuscript: MSC: mesenchymal stem cell; MRF: myogenic regulatory factor; MEF2: myocyte enhancer factor 2; miR-1: microRNA-1; LWS: low-weightselect; HWS: high-weight-select; qRT-PCR: quantitative real-time reverse-transcription polymerase chain reaction; LDM: longissimus dorsi muscle; PKA: protein kinase; Rb: retinoblastoma protein; E2F: E2 factor; ERK: extracellular signal-regulated kinase; FGF: fibroblast growth factor; IGF: insulin-like growth factor; mTOR: mammalian target of rapamycin; HGF: hepatocyte growth factor; TGF: transforming growth factor; BTA: bovine chromosome; DM: double-muscled; QTL: quantitative trait loci; GWAS: genome-wide association studies; CAST: calpastatin; SHISA 9: Shisa family member 9; MSL1: complex subunit 1; CDK: cyclin-dependent kinases; SNP: Single nucleotide polymorphism; NGS: Next-generation sequencing; MTPN: Myotrophin; GDF-8: myostatin; EMA: eye muscle area; ADG: average daily gain; OAR: ovine chromosome; MYLPF: myosin light chain phosphorylatable fast skeletal muscle; MYH: myosin heavy chains; TPM2: tropomyosin 2; TTN: Titin; LT: Lantang; LR: Landrace; DEG: differentially expressed genes; HH: Hamburger-Hamilton; TNNI1: troponin I; MB: myoglobin; MYL3: myosin, light chain 3; MBP: myelin basic protein; CSRP3: cysteine and glycine-rich protein 3; FHL2: four and a half LIM domains 2; HS6ST2: heparan sulfate 6-O-sulfotransferase 2; MUSTN1: musculoskeletal, embryonic nuclear protein 1; FGF16: fibroblast growth factor 16; INCENP: inner centromere protein antigens 135/155 kDa; and NDE1: NudE nuclear distribution gene E homolog 1 (A. nidulans).
\end{abstract}




\section{References}

1. Bentzinger, C.F.; Wang, Y.X.; Rudnicki, M.A. Building Muscle: Molecular Regulation of myogenesis. Cold Spring Harb. Perspect. Biol. 2012, 4, a008342. [CrossRef]

2. Mifflin, M.D.; St Jeor, S.T.; Hill, L.A.; Scott, B.J.; Daugherty, S.A.; Koh, Y.O. A new predictive equation for resting energy expenditure in healthy individuals. Am. J. Clin. Nutr. 1990, 51, 241-247. [CrossRef] [PubMed]

3. Nelson, K.M.; Weinsier, R.L.; Long, C.L.; Schutz, Y. Prediction of resting energy expenditure from fat-free mass and fat mass. Am. J. Clin. Nutr. 1992, 56, 848-856. [CrossRef]

4. Taguchi, M.; Ishikawa-Takata, K.; Tatsuta, W.; Katsuragi, C.; Usui, C.; Sakamoto, S.; Higuchi, M. Resting energy expenditure can be assessed by fat-free mass in female athletes regardless of body size. J. Nutr. Sci. Vitaminol. 2011, 57, 22-29. [CrossRef]

5. Wolfe, R.R. The underappreciated role of muscle in health and disease. Am. J. Clin. Nutr. 2006, 84, 475-482. [CrossRef]

6. DeFronzo, R.A.; Jacot, E.; Jequier, E.; Maeder, E.; Wahren, J.; Felber, J.P. The effect of insulin on the disposal of intravenous glucose. Results from indirect calorimetry and hepatic and femoral venous catheterization. Diabetes 1981, 30, 1000-1007. [CrossRef]

7. Du, M.; Tong, J.; Zhao, J.; Underwood, K.R.; Zhu, M.; Ford, S.P.; Nathanielsz, P.W. Fetal programming of skeletal muscle development in ruminant animals. J. Anim. Sci. 2010, 88, E51-E60. [CrossRef]

8. Parakati, R.; DiMario, J.X. Repression of myoblast proliferation and fibroblast growth factor receptor 1 promoter activity by KLF10 protein. J. Biol. Chem. 2013, 288, 13876-13884. [CrossRef]

9. Leatherland, J.F. Reflections on the thyroidology of fishes: From molecules to humankind. Guelph. Ichthyol. Rev. $1994,2,1-67$.

10. Rehfeldt, C.; Te Pas, M.F.W.; Wimmers, K.; Brameld, J.M.; Nissen, P.M.; Berri, C.; Valente, L.M.P.; Power, D.M.; Picard, B.; Stickland, N.C.; et al. Advances in research on the prenatal development of skeletal muscle in animals in relation to the quality of muscle-based food. Animal 2011, 5, 703-717. [CrossRef] [PubMed]

11. Shi, X.; Garry, D.J. Muscle stem cells in development, regeneration, and disease. Genes Dev. 2006, 20, 1692-1708. [CrossRef]

12. Meadows, E.; Cho, J.H.; Flynn, J.M.; Klein, W.H. Myogenin regulates a distinct genetic program in adult muscle stem cells. Dev. Biol. 2008, 322, 406-414. [CrossRef]

13. Knight, J.D.R.; Kothary, R. The myogenic kinome: Protein kinases critical to mammalian skeletal myogenesis. Skelet Muscle 2011, 1, 29. [CrossRef]

14. Zhao, L.; Huang, Y.; Du, M. Farm animals for studying muscle development and metabolism: Dual purposes for animal production and human ealth. Anim. Front. 2019, 9, 21-27. [CrossRef] [PubMed]

15. Berri, C.; Godet, E.; Haj Hattab, N.; Duclos, M.J. Growth and differentiation of the chicken Pectoralis major muscle: Effect of genotype and early nutrition. Arch. Anim. Breed. 2006, 49, 31-32.

16. Buckingham, M.; Mayeuf, A. Muscle. In Skeletal Muscle Development; Olson, J.A.H.N., Ed.; Academic Press: Boston, MA, USA, 2012; pp. 749-762.

17. Beermann, D.H.; Cassens, R.G.; Hausman, G.J. A second look at fiber type differentiation in porcine skeletal muscle. J. Anim. Sci. 1978, 46, 125-132. [CrossRef] [PubMed]

18. Fukada, S. The roles of muscle stem cells in muscle injury, atrophy and hypertrophy. J. Biochem. 2018, 163, 353-358. [CrossRef] [PubMed]

19. Buckingham, M. Skeletal muscle formation in vertebrates. Curr. Opin. Genet. Dev. 2001, 11, 440-448. [CrossRef]

20. Ridgeway, A.G.; Skerjanc, I.S. Pax3 is essential for skeletal myogenesis and the expression of Six1 and Eya2. J. Biol. Chem. 2001, 276, 19033-19039. [CrossRef]

21. Pownall, M.E.; Emerson, C.P. Sequential activation of three myogenic regulatory genes during somite morphogenesis in quail embryos. Dev. Biol. 1992, 151, 67-79. [CrossRef]

22. Coles, C.A.; Wadeson, J.; Leyton, C.P.; Siddell, J.P.; Greenwood, P.L.; White, J.D.; McDonagh, M.B. Proliferation rates of bovine primary muscle cells relate to live weight and carcase weight in cattle. PLoS ONE 2015, 10, e0124468. [CrossRef]

23. Yin, H.; Zhang, S.; Gilbert, E.R.; Siegel, P.B.; Zhu, Q.; Wong, E.A. Expression profiles of muscle genes in postnatal skeletal muscle in lines of chickens divergently selected for high and low body weight. Poult. Sci. 2014, 93, 147-154. [CrossRef]

24. Trukhachev, V.; Stavropol State Agrarian University; Skripkin, V.; Kvochko, A.; Kulichenko, A.; Kovalev, D.; Pisarenko, S.; Volynkina, A.; Selionova, M.; Aybazov, M.; et al. Correlation between gene expression profiles in muscle and live weight in Dzhalginsky Merino sheep. RCCP 2016, 29, 188-198. [CrossRef]

25. Ujan, J.A.; Zan, L.S.; Ujan, S.A.; Adoligbe, C.; Wang, H.B. Back fat thickness and meat tenderness are associated with a $526 \mathrm{~T} \rightarrow \mathrm{A}$ mutation in the exon 1 promoter region of the MyF-5 gene in Chinese Bos taurus. Genet. Mol. Res. 2011, 10, 3070-3079. [CrossRef] [PubMed]

26. Liu, M.; Peng, J.; Xu, D.; Zheng, R.; Li, F.; Li, J.; Zuo, B.; Lei, M.; Xiong, Y.; Deng, C.; et al. Association of MYF5 and MYOD1 gene polymorphisms and meat quality traits in Large White $\times$ Meishan F2 pig populations. Biochem. Genet. 2008, 46, 720-732. [CrossRef] [PubMed]

27. Ayuso, M.; Fernández, A.; Núñez, Y.; Benítez, R.; Isabel, B.; Fernández, A.I.; Rey, A.I.; González-Bulnes, A.; Medrano, J.F.; Cánovas, A.; et al. Developmental Stage, Muscle and Genetic Type Modify Muscle Transcriptome in Pigs: Effects on Gene Expression and Regulatory Factors Involved in Growth and Metabolism. PLoS ONE 2016, 11, e0167858. [CrossRef]

28. Chen, A.E.; Ginty, D.D.; Fan, C.M. Protein kinase A signalling via CREB controls myogenesis induced by Wnt proteins. Nature 2005, 433, 317-322. [CrossRef] 
29. Skapek, S.X.; Rhee, J.; Kim, P.S.; Novitch, B.G.; Lassar, A.B. Cyclin-mediated inhibition of muscle gene expression via a mechanism that is independent of pRB hyperphosphorylation. Mol. Cell. Biol. 1996, 16, 7043-7053. [CrossRef] [PubMed]

30. Gu, W.; Schneider, J.W.; Condorelli, G.; Kaushal, S.; Mahdavi, V.; Nadal-Ginard, B. Interaction of myogenic factors and the retinoblastoma protein mediates muscle cell commitment and differentiation. Cell 1993, 72, 309-324. [CrossRef]

31. Nagata, Y.; Takahashi, N.; Davis, R.J.; Todokoro, K. Activation of p38 MAP kinase and JNK but not ERK is required for erythropoietin-induced erythroid differentiation. Blood 1998, 92, 1859-1869. [CrossRef]

32. Morooka, T.; Nishida, E. Requirement of p38 mitogen-activated protein kinase for neuronal differentiation in PC12 cells. J. Biol. Chem. 1998, 273, 24285-24288. [CrossRef]

33. Bhat, N.R.; Zhang, P.; Mohanty, S.B. p38 MAP kinase regulation of oligodendrocyte differentiation with CREB as a potential target. Neurochem. Res. 2007, 32, 293-302. [CrossRef]

34. Li, Y.; Jiang, B.; Ensign, W.Y.; Vogt, P.K.; Han, J. Myogenic differentiation requires signalling through both phosphatidylinositol 3-kinase and p38 MAP kinase. Cell Signal. 2000, 12, 751-757. [CrossRef]

35. Sarker, K.P.; Lee, K.Y. L6 myoblast differentiation is modulated by Cdk5 via the PI3K-AKT-p70S6K signaling pathway. Oncogene 2004, 23, 6064-6070. [CrossRef] [PubMed]

36. Cabane, C.; Coldefy, A.S.; Yeow, K.; Dérijard, B. The p38 pathway regulates Akt both at the protein and transcriptional activation levels during myogenesis. Cell Signal. 2004, 16, 1405-1415. [CrossRef]

37. Lai, K.M.V.; Gonzalez, M.; Poueymirou, W.T.; Kline, W.O.; Na, E.; Zlotchenko, E.; Stitt, T.N.; Economides, A.N.; Yancopoulos, G.D.; Glass, D.J. Conditional activation of akt in adult skeletal muscle induces rapid hypertrophy. Mol. Cell. Biol. 2004, 24, 9295-9304. [CrossRef]

38. Héron-Milhavet, L.; Franckhauser, C.; Rana, V.; Berthenet, C.; Fisher, D.; Hemmings, B.A. Only Akt1 is required for proliferation, while Akt2 promotes cell cycle exit through p21 binding. Mol. Cell. Biol. 2006, 26, 8267-8280. [CrossRef] [PubMed]

39. Héron-Milhavet, L.; Mamaeva, D.; Rochat, A.; Lamb, N.J.C.; Fernandez, A. Akt2 is implicated in skeletal muscle differentiation and specifically binds Prohibitin2/REA. J. Cell Physiol. 2008, 214, 158-165. [CrossRef] [PubMed]

40. Rochat, A.; Fernandez, A.; Vandromme, M.; Molès, J.P.; Bouschet, T.; Carnac, G.; Lamb, N.J.C. Insulin and wnt1 pathways cooperate to induce reserve cell activation in differentiation and myotube hypertrophy. Mol. Biol. Cell 2004, 15, 4544-4555. [CrossRef] [PubMed]

41. Van der Velden, J.L.J.; Langen, R.C.J.; Kelders, M.C.J.M.; Wouters, E.F.M.; Janssen-Heininger, Y.M.W.; Schols, A.M.W.J. Inhibition of glycogen synthase kinase-3 $\beta$ activity is sufficient to stimulate myogenic differentiation. Am. J. Physiol. Cell Physiol. 2006, 290, C453-C462. [CrossRef] [PubMed]

42. Pansters, N.A.M.; van der Velden, J.L.J.; Kelders, M.C.J.M.; Laeremans, H.; Schols, A.M.W.J.; Langen, R.C.J. Segregation of myoblast fusion and muscle-specific gene expression by distinct ligand-dependent inactivation of GSK-3ß. Cell. Mol. Life Sci. 2011, 68, 523-535. [CrossRef]

43. Bodine, S.C.; Stitt, T.N.; Gonzalez, M.; Kline, W.O.; Stover, G.L.; Bauerlein, R.; Zlotchenko, E.; Scrimgeour, A.; Lawrence, J.C.; Glass, D.J.; et al. Akt/mTOR pathway is a crucial regulator of skeletal muscle hypertrophy and can prevent muscle atrophy in vivo. Nat. Cell Biol. 2001, 3, 1014-1019. [CrossRef] [PubMed]

44. Pallafacchina, G.; Calabria, E.; Serrano, A.L.; Kalhovde, J.M.; Schiaffino, S. A protein kinase B-dependent and rapamycin-sensitive pathway controls skeletal muscle growth but not fiber type specification. Proc. Natl. Acad. Sci. USA 2002, 99, 9213-9218. [CrossRef] [PubMed]

45. Shu, L.; Houghton, P.J. The mTORC2 complex regulates terminal differentiation of C2C12 myoblasts. Mol. Cell. Biol. 2009, 29, 4691-4700. [CrossRef]

46. Ge, Y.; Wu, A.L.; Warnes, C.; Liu, J.; Zhang, C.; Kawasome, H.; Terada, N.; Boppart, M.D.; Schoenherr, C.J.; Chen, J. mTOR regulates skeletal muscle regeneration in vivo through kinase-dependent and kinase-independent mechanisms. Am. J. Physiol. Cell Physiol. 2009, 297, C1434-C1444. [CrossRef]

47. Sun, Y.; Ge, Y.; Drnevich, J.; Zhao, Y.; Band, M.; Chen, J. Mammalian target of rapamycin regulates miRNA-1 and follistatin in skeletal myogenesis. J. Cell Biol. 2010, 189, 1157-1169. [CrossRef] [PubMed]

48. Joe, A.W.B.; Yi, L.; Natarajan, A.; Grand, F.L.; So, L.; Wang, J.; Rudnicki, M.A.; Rossi, F.M.V. Muscle injury activates resident fibro/adipogenic progenitors that facilitate myogenesis. Nat. Cell Biol. 2010, 12, 153-163. [CrossRef]

49. Uezumi, A.; Fukada, S.; Yamamoto, N.; Takeda, S.; Tsuchida, K. Mesenchymal progenitors distinct from satellite cells contribute to ectopic fat cell formation in skeletal muscle. Nat. Cell Biol. 2010, 12, 143-152. [CrossRef]

50. Muoio, D.M.; Way, J.M.; Tanner, C.J.; Winegar, D.A.; Kliewer, S.A.; Houmard, J.A.; Kraus, W.E.; Dohm, G.L. Peroxisome proliferator-activated receptor-a regulates fatty acid utilization in primary human skeletal muscle cells. Diabetes 2002, 51, 901-909. [CrossRef] [PubMed]

51. Koh, E.H.; Kim, M.; Park, J.; Kim, H.S.; Youn, J.; Park, H.; Youn, J.H.; Lee, K. Peroxisome proliferator-activated receptor (PPAR)alpha activation prevents diabetes in OLETF rats: Comparison with PPAR-gamma activation. Diabetes 2003, 52, $2331-2337$. [CrossRef]

52. Oberkofler, H.; Esterbauer, H.; Linnemayr, V.; Strosberg, A.D.; Krempler, F.; Patsch, W. Peroxisome proliferator-activated receptor (PPAR) gamma coactivator-1 recruitment regulates PPAR subtype specificity. J. Biol. Chem. 2002, 277, 16750-16757. [CrossRef]

53. Yu, Y.H.; Liu, B.H.; Mersmann, H.J.; Ding, S.T. Porcine peroxisome proliferator-activated receptor gamma induces transdifferentiation of myocytes into adipocytes. J. Anim. Sci. 2006, 84, 2655-2665. [CrossRef] 
54. Wang, Y.; Lee, C.; Tiep, S.; Yu, R.T.; Ham, J.; Kang, H.; Evans, R.M. Peroxisome-proliferator-activated receptor delta activates fat metabolism to prevent obesity. Cell 2003, 113, 159-170. [CrossRef]

55. Holst, D.; Luquet, S.; Nogueira, V.; Kristiansen, K.; Leverve, X.; Grimaldi, P.A. Nutritional regulation and role of peroxisome proliferator-activated receptor delta in fatty acid catabolism in skeletal muscle. Biochim. Biophys. Acta 2003, 1633, 43-50. [CrossRef]

56. Wu, Z.; Rosen, E.D.; Brun, R.; Hauser, S.; Adelmant, G.; Troy, A.E.; McKeon, C.; Darlington, G.J.; Spiegelman, B.M. Crossregulation of $\mathrm{C} / \mathrm{EBP} \alpha$ and PPAR $\gamma$ controls the transcriptional pathway of adipogenesis and insulin sensitivity. Mol. Cell 1999, 3, 151-158. [CrossRef]

57. Xue, P.; Hou, Y.; Zuo, Z.; Wang, Z.; Ren, S.; Dong, J.; Fu, J.; Wang, H.; Andersen, M.E.; Zhang, Q.; et al. Long isoforms of NRF1 negatively regulate adipogenesis via suppression of PPAR $\gamma$ expression. Redox Biol. 2020, 30, 101414. [CrossRef] [PubMed]

58. Cassar-Malek, I.; Bonnet, M.; Chilliard, Y.; Picard, B. Cross-talk between myoblasts, adipocytes and fibroblasts during bovine myogenesis. COST Action 925-The importance of prenatal events for postnatal muscle growth in relation to the quality of muscle based foods. In Proceedings of the 3rd Work Group Meeting, Antalya, Turkey, 21-22 September 2006.

59. Bonnet, M.; Cassar-Malek, I.; Chilliard, Y.; Picard, B. Ontogenesis of muscle and adipose tissues and their interactions in ruminants and other species. Animal 2010, 4, 1093-1109. [CrossRef]

60. Bandow, K.; Ohnishi, T.; Tamura, M.; Semba, I.; Daikuhara, Y. Hepatocyte growth factor/scatter factor stimulates migration of muscle precursors in developing mouse tongue. J. Cell Physiol. 2004, 201, 236-243. [CrossRef] [PubMed]

61. Lapin, M.R.; Gonzalez, J.M.; Johnson, S.E. Substrate elasticity affects bovine satellite cell activation kinetics in vitro. J. Anim. Sci. 2013, 91, 2083-2090. [CrossRef]

62. Velleman, S.G. Muscle development in the embryo and hatchling. Poult. Sci. 2007, 86, 1050-1054. [CrossRef] [PubMed]

63. Brunetti, A.; Goldfine, I.D. Role of myogenin in myoblast differentiation and its regulation by fibroblast growth factor. J. Biol. Chem. 1990, 265, 5960-5963. [CrossRef]

64. Kamanga-Sollo, E.; Pampusch, M.S.; White, M.E.; Dayton, W.R. Role of insulin-like growth factor binding protein (IGFBP)-3 in TGF $\beta$-and GDF 8 (myostatin)-induced suppression of proliferation in porcine embryonic myogenic cell cultures. J. Cell Physiol. 2003, 197, 225-231. [CrossRef]

65. Shahjahan, M.D. Skeletal muscle development in vertebrate animals. Asian J. Med. Biol. Res. 2015, 1, 139-148. [CrossRef]

66. Wu, G.; Siegel, P.B.; Gilbert, E.R.; Yang, N.; Wong, E.A. Expression profiles of somatotropic axis genes in lines of chickens divergently selected for 56-day body weight. Anim. Biotechnol. 2011, 22, 100-110. [CrossRef]

67. Theil, P.K.; Sørensen, I.L.; Nissen, P.M.; Oksbjerg, N. Temporal expression of growth factor genes of primary porcine satellite cells during myogenesis. Anim. Sci. J. 2006, 77, 330-337. [CrossRef]

68. Fahey, A.J.; Brameld, J.M.; Parr, T.; Buttery, P.J. Ontogeny of factors associated with proliferation and differentiation of muscle in the ovine fetus. J. Anim. Sci. 2005, 83, 2330-2338. [CrossRef] [PubMed]

69. Gerrard, D.E.; Grant, A.L. Insulin-like growth factor-II expression in developing skeletal muscle of double muscled and normal cattle. Domest. Anim. Endocrinol. 1994, 11, 339-347. [CrossRef]

70. Setoguchi, K.; Furuta, M.; Hirano, T.; Nagao, T.; Watanabe, T.; Sugimoto, Y.; Takasuga, A. Cross-breed comparisons identified a critical 591-kb region for bovine carcass weight QTL (CW-2) on chromosome 6 and the Ile-442-Met substitution in NCAPG as a positional candidate. BMC Genet. 2009, 10, 43. [CrossRef]

71. Clure, M.C.; Morsci, N.S.; Schnabel, R.D.; Kim, J.W.; Yao, P.; Rolf, M.M.; McKay, S.D.; Gregg, S.J.; Chapple, R.H.; Northcutt, S.L.; et al. A genome scan for quantitative trait loci influencing carcass, post-natal growth and reproductive traits in commercial Angus cattle. Anim. Genet. 2010, 41, 597-607. [CrossRef]

72. Nishimura, S.; Watanabe, T.; Mizoshita, K.; Tatsuda, K.; Fujita, T.; Watanabe, N.; Sugimoto, Y.; Takasuga, A. Genome-wide association study identified three major QTL for carcass weight including the PLAG1-CHCHD7 QTN for stature in Japanese Black cattle. BMC Genet. 2012, 13, 40. [CrossRef]

73. Takasuga, A.; Watanabe, T.; Mizoguchi, Y.; Hirano, T.; Ihara, N.; Takano, A.; Yokouchi, K.; Fujikawa, A.; Chiba, K.; Kobayashi, N.; et al. Identification of bovine QTL for growth and carcass traits in Japanese Black cattle by replication and identical-by-descent mapping. Mamm. Genome 2017, 18, 125-136. [CrossRef]

74. Bordbar, F.; Jensen, J.; Zhu, B.; Wang, Z.; Xu, L.; Chang, T.; Xu, L.; Du, M.; Zhang, L.; Gao, H.; et al. Identification of muscle-specific candidate genes in Simmental beef cattle using imputed next generation sequencing. PLoS ONE 2019, 14, e0223671. [CrossRef]

75. McDaneld, T.G.; Hancock, D.L.; Moody, D.E. Altered mRNA abundance of ASB15 and four other genes in skeletal muscle following administration of $\beta$-adrenergic receptor agonists. Physiol. Genomics 2004, 16, 275-283. [CrossRef]

76. McDaneld, T.G.; Spurlock, D.M. Ankyrin repeat and suppressor of cytokine signaling (SOCS) box-containing protein (ASB) 15 alters differentiation of mouse $\mathrm{C} 2 \mathrm{C} 12$ myoblasts and phosphorylation of mitogen-activated protein kinase and Akt1. J. Anim. Sci. 2008, 86, 2897-2902. [CrossRef] [PubMed]

77. Ackrell, B.A.; Maguire, J.J.; Dallman, P.R.; Kearney, E.B. Effect of iron deficiency on succinate- and NADH-ubiquinone oxidoreductases in skeletal muscle mitochondria. J. Biol. Chem. 1984, 259, 10053-10059. [CrossRef]

78. Seong, J.; Yoon, H.; Kong, H.S. Identification of microRNA and target gene associated with marbling score in Korean cattle (Hanwoo). Genes Genomics 2016, 38, 529-538. [CrossRef]

79. Li, K.; Ma, Y.; Zhang, Z.; Tian, Y.; Xu, X.; He, Y.; Xu, L.; Gao, Y.; Pan, W.; Song, W.; et al. Upregulated IQUB promotes cell proliferation and migration via activating Akt/GSK3 $\beta / \beta$-catenin signaling pathway in breast cancer. Cancer Med. 2018, 7, 3875-3888. [CrossRef] [PubMed] 
80. Yu, S.L.; Chung, H.J.; Sang, B.C.; Park, C.S.; Lee, J.H.; Yoon, D.H.; Lee, S.H.; Choi, K.D. Identification of differentially expressed genes in distinct skeletal muscles in cattle using cDNA microarray. Anim. Biotechnol. 2007, 18, 275-285. [CrossRef] [PubMed]

81. Pinto, C.S.; Khandekar, A.; Bhavana, R.; Kiesel, P.; Pigino, G.; Sonawane, M. Microridges are apical projections formed of branched F-actin networks that organize the glycan layer. Biorxiv 2018. [CrossRef]

82. Bordbar, F.; Jensen, J.; Du, M.; Abied, A.; Guo, W.; Xu, L.; Gao, H.; Zhang, L.; Li, J. Identification and validation of a novel candidate gene regulating net meat weight in Simmental beef cattle based on imputed next-generation sequencing. Cell Prolif. 2020, 53, e12870. [CrossRef] [PubMed]

83. Wang, L.; Wang, Y. Molecular characterization, expression patterns and subcellular localization of Myotrophin (MTPN) gene in porcine skeletal muscle. Mol. Biol. Rep. 2012, 39, 2733-2738. [CrossRef]

84. Hayashi, T.; Ogawa, T.; Sato, M.; Tsuchida, N.; Fotovati, A.; Iwamoto, H.; Ikeuchi, Y.; Cassens, R.G.; Ito, T. S-myotrophin promotes the hypertrophy of myotube as insulin-like growth factor-I does. Int. J. Biochem. Cell Biol. 2001, 33, 831-838. [CrossRef]

85. Kim, Y.; Ryu, J.; Woo, J.; Kim, J.B.; Kim, C.Y.; Lee, C. Genome-wide association study reveals five nucleotide sequence variants for carcass traits in beef cattle. Anim. Genet. 2011, 42, 361-365. [CrossRef] [PubMed]

86. Pizzuti, A.; Amati, F.; Calabrese, G.; Mari, A.; Colosimo, A.; Silani, V.; Giardino, L.; Ratti, A.; Penso, D.; Calzà, L.; et al. cDNA characterization and chromosomal mapping of two human homologues of the Drosophila dishevelled polarity gene. Hum. Mol. Genet. 1996, 5, 953-958. [CrossRef] [PubMed]

87. Luo, Z.G.; Wang, Q.; Zhou, J.Z.; Wang, J.; Luo, Z.; Liu, M.; He, X.; Wynshaw-Boris, A.; Xiong, W.C.; Lu, B.; et al. Regulation of AChR clustering by Dishevelled interacting with MuSK and PAK1. Neuron 2002, 35, 489-505. [CrossRef]

88. Liu, Y.; Duan, X.; Chen, S.; He, H.; Liu, X. NCAPG is differentially expressed during longissimus muscle development and is associated with growth traits in Chinese Qinchuan beef cattle. Genet. Mol. Biol. 2015, 38, 450-456. [CrossRef]

89. Lindholm-Perry, A.K.; Kuehn, L.A.; Oliver, W.T.; Sexten, A.K.; Miles, J.R.; Rempel, L.A.; Cushman, R.A.; Freetly, H.C. Adipose and muscle tissue gene expression of two genes (NCAPG and LCORL) located in a chromosomal region associated with cattle feed intake and gain. PLoS ONE 2013, 8, e80882. [CrossRef]

90. Zhuang, Z.; Xu, L.; Yang, J.; Gao, H.; Zhang, L.; Gao, X.; Li, J.; Zhu, B. Weighted Single-Step Genome-Wide Association Study for Growth Traits in Chinese Simmental Beef Cattle. Genes 2020, 11, 189. [CrossRef]

91. Marques, D.B.D.; Bastiaansen, J.W.M.; Broekhuijse, M.L.W.J.; Lopes, M.S.; Knol, E.F.; Harlizius, B.; Guimarães, S.E.F.; Silva, F.F.; Lopes, P.S. Weighted single-step GWAS and gene network analysis reveal new candidate genes for semen traits in pigs. Genet. Sel. Evol. 2018, 50, 40. [CrossRef]

92. Harten, S.K.; Oey, H.; Bourke, L.M.; Bharti, V.; Isbel, L.; Daxinger, L.; Faou, P.; Robertson, N.; Matthews, J.M.; Whitelaw, E. The recently identified modifier of murine metastable epialleles, Rearranged L-Myc Fusion, is involved in maintaining epigenetic marks at CpG island shores and enhancers. BMC Biol. 2015, 13, 21. [CrossRef]

93. Wegner, J.; Albrecht, E.; Ender, K. Morphological aspects of growth in subcutaneous and intramuscular adipocytes in cattle. Arch. Tierz. 1998, 41, 313-320.

94. Jurie, C.; Cassar-Malek, I.; Bonnet, M.; Leroux, C.; Bauchart, D.; Boulesteix, P.; Pethick, D.W.; Hocquette, J.F. Adipocyte fatty acid-binding protein and mitochondrial enzyme activities in muscles as relevant indicators of marbling in cattle. J. Anim. Sci. 2007, 85, 2660-2669. [CrossRef] [PubMed]

95. Du, M.; Huang, Y.; Das, A.K.; Yang, Q.; Duarte, M.S.; Dodson, M.V.; Zhu, M. Meat Science and Muscle Biology Symposium: Manipulating mesenchymal progenitor cell differentiation to optimize performance and carcass value of beef cattle. J. Anim. Sci. 2013, 91, 1419-1427. [CrossRef]

96. Hudson, N.J.; Reverter, A.; Greenwood, P.L.; Guo, B.; Cafe, L.M.; Dalrymple, B.P. Longitudinal muscle gene expression patterns associated with differential intramuscular fat in cattle. Animal 2015, 9, 650-659. [CrossRef] [PubMed]

97. Lehnert, S.A.; Reverter, A.; Byrne, K.A.; Wang, Y.; Nattrass, G.S.; Hudson, N.J.; Greenwood, P.L. Gene expression studies of developing bovine longissimus muscle from two different beef cattle breeds. BMC Dev. Biol. 2007, 7, 95. [CrossRef] [PubMed]

98. Bergstrom, D.A.; Penn, B.H.; Strand, A.; Perry, R.L.S.; Rudnicki, M.A.; Tapscott, S.J. Promoter-specific regulation of MyoD binding and signal transduction cooperate to pattern gene expression. Mol. Cell 2002, 9, 587-600. [CrossRef]

99. Grigoletto, L.; Brito, L.F.; Mattos, E.C.; Eler, J.P.; Bussiman, F.O.; Silva, B.D.C.A.; Silva, R.P.; Carvalho, F.E.; Berton, M.P.; Baldi, F.; et al. Genome-wide associations and detection of candidate genes for direct and maternal genetic effects influencing growth traits in the Montana Tropical ${ }^{\circledR}$ Composite population. Livest. Sci. 2019, 229, 64-76. [CrossRef]

100. Zhang, R.; Miao, J.; Song, Y.; Zhang, W.; Xu, L.; Chen, Y.; Zhang, L.; Gao, H.; Zhu, B.; Li, J.; et al. Genome-wide association study identifies the PLAG1-OXR1 region on BTA14 for carcass meat yield in cattle. Physiol. Genomics 2019, 51, 137-144. [CrossRef]

101. Cali-Daylan, A.E.; Dincer, P. Gene co-expression network analysis of dysferlinopathy: Altered cellular processes and functional prediction of TOR1AIP1, a novel muscular dystrophy gene. Neuromuscul. Disord. 2017, 27, 269-277. [CrossRef]

102. Crispim, A.C.; Kelly, M.J.; Guimarães, S.E.F.; Silva, F.F.E.; Fortes, M.R.S.; Wenceslau, R.R.; Moore, S. Multi-Trait GWAS and New Candidate Genes Annotation for Growth Curve Parameters in Brahman Cattle. PLoS ONE 2015, 10, e0139906. [CrossRef]

103. Jiang, J.; Qi, Y.; Zhang, P.; Gu, W.; Yan, Z.; Shen, B.R.; Yao, Q.; Kong, H.; Chien, S.; Jiang, Z. Involvement of Rab28 in NF-kB Nuclear Transport in Endothelial Cells. PLoS ONE 2013, 8, e56076. [CrossRef] [PubMed]

104. Rodier, A.; Rochard, P.; Berthet, C.; Rouault, J.P.; Casas, F.; Daury, L.; Busson, M.; Magaud, J.P.; Wrutniak-Cabello, C.; Cabello, G. Identification of functional domains involved in BTG1 cell localization. Oncogene 2001, 20, 2691-2703. [CrossRef] [PubMed] 
105. Busson, M.; Carazo, A.; Seyer, P.; Grandemange, S.; Casas, F.; Pessemesse, L.; Rouault, J.; Wrutniak-Cabello, C.; Cabello, G. Coactivation of nuclear receptors and myogenic factors induces the major BTG1 influence on muscle differentiation. Oncogene 2005, 24, 1698-1710. [CrossRef] [PubMed]

106. Cifuentes-Diaz, C.; Frugier, T.; Tiziano, F.D.; Lacène, E.; Roblot, N.; Joshi, V.; Moreau, M.H.; Melki, J. Deletion of murine SMN exon 7 directed to skeletal muscle leads to severe muscular dystrophy. J. Cell Biol. 2001, 152, 1107-1114. [CrossRef]

107. White, J.D.; Vuocolo, T.; McDonagh, M.; Grounds, M.D.; Harper, G.S.; Cockett, N.E.; Tellam, R. Analysis of the callipyge phenotype through skeletal muscle development; association of Dlk1 with muscle precursor cells. Differentiation 2008, 76, 283-298. [CrossRef]

108. Smit, M.A. Long-Range Transcriptional Regulation at the Ovine Callipyge Imprinted Gene Cluster. Ph.D. Dissertation, Utah State University, Logan, UT, USA, 2004. Available online: https:/ / search.proquest.com/openview/7176b2e794d3ef1503cff1b51cb77c4 $1 / 1$ ?pqorigsite $=$ gscholar\&cbl=18750\&diss $=y$ (accessed on 15 December 2020).

109. Kobayashi, S.; Wagatsuma, H.; Ono, R.; Ichikawa, H.; Yamazaki, M.; Tashiro, H.; Aisaka, K.; Miyoshi, N.; Kohda, T.; Ogura, A.; et al. Mouse Peg9/Dlk1 and human PEG9/DLK1 are paternally expressed imprinted genes closely located to the maternally expressed imprinted genes: Mouse Meg3/Gt12 and human MEG3. Genes Cells 2000, 5, 1029-1037. [CrossRef]

110. Charlier, C.; Segers, K.; Wagenaar, D.; Karim, L.; Berghmans, S.; Jaillon, O.; Shay, T.; Weissenbach, J.; Cockett, N.; Gyapay, G.; et al. Human-ovine comparative sequencing of a 250-kb imprinted domain encompassing the callipyge (clpg) gene and identification of six imprinted transcripts: DLK1, DAT, GTL2, PEG11, antiPEG11, and MEG8. Genome Res. 2001, 11, 850-862. [CrossRef]

111. Hernandez, A.; Fiering, S.; Martinez, E.; Galton, V.A.; Germain, D.S. The gene locus encoding iodothyronine deiodinase type 3 (Dio3) is imprinted in the fetus and expresses antisense transcripts. Endocrinology 2002, 143, 4483-4486. [CrossRef]

112. Miyoshi, N.; Wagatsuma, H.; Wakana, S.; Shiroishi, T.; Nomura, M.; Aisaka, K.; Kohda, T.; Surani, M.A.; Kaneko-Ishino, T.; Ishino, F. Identification of an imprinted gene, Meg3/Gt12 and its human homologue MEG3, first mapped on mouse distal chromosome 12 and human chromosome 14q. Genes Cells 2000, 5, 211-220. [CrossRef]

113. Seitz, H.; Youngson, N.; Lin, S.P.; Dalbert, S.; Paulsen, M.; Bachellerie, J.P.; Ferguson-Smith, A.C.; Cavaillé, J. Imprinted microRNA genes transcribed antisense to a reciprocally imprinted retrotransposon-like gene. Nat. Genet. 2003, 34, 261-262. [CrossRef]

114. Nicoll, G.B.; Burkin, H.R.; Broad, T.E.; Jopson, N.B.; Greer, G.J.; Bain, W.E.; Wright, C.S.; Dodds, K.G.; Fennessy, P.; McEwan, J.C. Genetic linkage of microsatellite markers to the Carwell locus for rib-eye muscling in sheep. In Proceedings of the 6th World Congress of Genetics Applied to Livestock, Armidale, Australia, 11-16 January 1998; Volume 26, pp. 529-532. [CrossRef]

115. McEwan, J.C.; Broad, T.E.; Jopson, N.B.; Robertson, T.M.; Glass, B.C.; Burkin, H.B. Rib-eye muscling (REM) locus in sheep: Phenotypic effects and comparative genome localization. In Proceedings of the 27th Conference of the International Society of Animal Genetics, Minneapolis, MN, USA, 22-26 July 2000; Volume 7. [CrossRef]

116. Knapik, J.; Ropka-Molik, K.; Pieszka, M. Genetic and Nutritional Factors Determining the Production and Quality of Sheep Meat-A Review. Ann. Anim. Sci. 2017, 17, 23-40. [CrossRef]

117. Clop, A.; Marcq, F.; Takeda, H.; Pirottin, D.; Tordoir, X.; Bibé, B.; Bouix, J.; Caiment, F.; Elsen, J.; Eychenne, F.; et al. A mutation creating a potential illegitimate microRNA target sites in the myostatin gene affects muscularity in sheep. Nat. Genet. 2006, 38, 813-818. [CrossRef]

118. Kijas, J.W.; McCullloch, R.; Hocking Edwards, J.E.; Hutton Oddy, V.; Lee, S.H.; Van der Werf, J. Evidence for multiple alleles effecting muscling and fatness at the ovine GDF8 locus. BMC Genet. 2007, 8, 80. [CrossRef]

119. Gan, S.Q.; Du, Z.; Liu, S.R.; Yang, Y.L.; Shen, M.; Wang, X.H.; Yin, J.L.; Hu, X.X.; Fei, J.; Fan, J.J.; et al. Association of SNP haplotypes at the myostatin gene with muscular hypertrophy in sheep. AJAS 2008, 21, 928-935. [CrossRef]

120. Bagatoli, A.; Gasparino, E.; Soares, M.A.M.; Amaral, R.M.; Macedo, F.A.F.; Voltolini, D.M.; Vesco, A.P.D. Expression of calpastatin and myostatin genes associated with lamb meat quality. Genet. Mol. Res. 2013, 12, 6168-6175. [CrossRef] [PubMed]

121. Koohmaraie, M.; Kent, M.P.; Shackelford, S.D.; Veiseth, E.; Wheeler, T.L. Meat tenderness and muscle growth: Is there any relationship? Meat Sci. 2002, 62, 345-352. [CrossRef]

122. Goll, E.G.; Thompson, V.Y.F.; Li, H.; Wei, W.; Cong, J. The calpain system. Physiol. Rev. 2003, 83, 731-801. [CrossRef] [PubMed]

123. Wendt, A.; Thompson, V.F.; Goll, D.E. Interaction of calpastatin with calpain: A review. Biol. Chem. 2004, 385, 465-472. [CrossRef] [PubMed]

124. Nikmard, M.; Vahid Molaee, V.; Eskandarinasab, M.P.; Djadid, N.D.; Vajhi, A.R. Calpastatin polymorphism in Afshari sheep and its possible correlation with growth and carcass traits. J. Appl. Anim. Res. 2012, 40, 346-350. [CrossRef]

125. Wang, H.; Zhang, L.; Cao, J.; Wu, M.; Ma, X.; Liu, Z.; Liu, R.; Zhao, F.; Wei, C.; Du, L. Genome-wide specific selection in three domestic sheep breeds. PLoS ONE 2015, 10, e0128688. [CrossRef] [PubMed]

126. Kominakis, A.; Hager-Theodorides, A.L.; Zoidis, E.; Saridaki, A.; Antonakos, G.; Tsiamis, G. Combined GWAS and 'guilt by association'-based prioritization analysis identifies functional candidate genes for body size in sheep. Genet. Sel. Evol. 2017, 49, 41. [CrossRef]

127. Zhang, L.; Liu, J.; Zhao, F.; Ren, H.; Xu, L.; Lu, J.; Zhang, S.; Zhang, X.; Wei, C.; Lu, G.; et al. Genome-wide association studies for growth and meat production traits in sheep. PLoS ONE 2013, 8, e66569. [CrossRef]

128. Fogarty, N.M. A review of the effects of the Booroola gene (FecB) on sheep production. Small Rumin. Res. 2009, 85, 75-84. [CrossRef] 
129. Arora, R.; Kumar, S.N.; Sudarshan, S.; Fairoze, M.N.; Kaur, M.; Sharma, A.; Girdhar, Y.; Sreesujatha, R.M.; Devatkal, S.K.; Ahlawat, S.; et al. Transcriptome profiling of longissimus thoracis muscles identifies highly connected differentially expressed genes in meat type sheep of India. PLoS ONE 2019, 14, e0217461. [CrossRef] [PubMed]

130. Noce, A.; Cardoso, T.F.; Manunza, A.; Martínez, A.; Cánovas, A.; Pons, A.; Bermejo, L.A.; Landi, V.; Sànchez, A.; Jordana, J.; et al. Expression patterns and genetic variation of the ovine skeletal muscle transcriptome of sheep from five Spanish meat breeds. Sci. Rep. 2018, 8, 10486. [CrossRef] [PubMed]

131. Fan, Y.; Liang, Y.; Deng, K.; Zhang, Z.; Zhang, G.; Zhang, Y.; Wang, F. Analysis of DNA methylation profiles during sheep skeletal muscle development using whole-genome bisulfite sequencing. BMC Genomics 2020, 21, 327. [CrossRef]

132. Guðmundsdóttir, Ó.Ó. Genome-Wide Association Study of Muscle Traits in Icelandic Sheep. Master's Thesis, Agricultural University of Iceland, Hvanneyri, Iceland, 2015. Available online: http:/ /hdl.handle.net/1946/20392 (accessed on 18 December 2020).

133. Flicek, P.; Amode, M.R.; Barrell, D.; Beal, K.; Billis, K.; Brent, S.; Carvalho-Silva, D.; Clapham, P.; Coates, G.; Fitzgerald, S.; et al. Ensembl 2014. Nucleic Acids Res 2014, 42, D749-D755. [CrossRef] [PubMed]

134. Cao, Y.; Jin, H.; Ma, H.; Zhao, Z. Comparative analysis on genome-wide DNA methylation in longissimus dorsi muscle between Small Tailed Han and Dorper $\times$ Small Tailed Han crossbred sheep. Asian-Australas. J. Anim. Sci. 2017, 30, 1529-1539. [CrossRef] [PubMed]

135. Boucher, D.; Palin, M.F.; Castonguay, F.; Gariépy, C.; Pothier, F. Detection of polymorphisms in the ovine leptin (LEP) gene: Association of a single nucleotide polymorphism with muscle growth and meat quality traits. Can. J. Anim. Sci. 2006, 86, 31-35. [CrossRef]

136. Sadeghi, S.; Hajihosseinlo, A.; Bohlouli, M. Haplotype association of ovine leptin gene on breeding value of body measurements in Makooei sheep breed. Biotechnol. Anim. Husb. 2014, 30, 233-242. [CrossRef]

137. Xu, Q.L.; Tang, G.W.; Zhang, Q.L.; Huang, Y.K.; Liu, Y.X.; Quan, K.; Zhu, K.Y.; Zhang, C.X. The FABP4 gene polymorphism is associated with meat tenderness in three Chinese native sheep breeds. Czech J. Anim. Sci. 2011, 56, 1-6. [CrossRef]

138. Zhao, X.; Mo, D.; Li, A.; Gong, W.; Xiao, S.; Zhang, Y.; Qin, L.; Niu, Y.; Guo, Y.; Liu, X.; et al. Comparative analyses by sequencing of transcriptomes during skeletal muscle development between pig breeds differing in muscle growth rate and fatness. PLoS ONE 2011, 6, e19774. [CrossRef]

139. Zhao, Y.; Li, J.; Liu, H.; Xi, Y.; Xue, M.; Liu, W.; Zhuang, Z.; Lei, M. Dynamic transcriptome profiles of skeletal muscle tissue across 11 developmental stages for both Tongcheng and Yorkshire pigs. BMC Genomics 2015, 16, 377. [CrossRef]

140. Ayuso, M.; Fernández, A.; Núñez, Y.; Benítez, R.; Isabel, B.; Barragán, C.; Fernández, A.I.; Rey, A.I.; Medrano, J.F.; Cánovas, Á.; et al. Comparative Analysis of Muscle Transcriptome between Pig Genotypes Identifies Genes and Regulatory Mechanisms Associated to Growth, Fatness and Metabolism. PLoS ONE 2015, 10, e0145162. [CrossRef] [PubMed]

141. Ovilo, C.; Benítez, R.; Fernández, A.; Núñez, Y.; Ayuso, M.; Fernández, A.I.; Rodríguez, C.; Isabel, B.; Rey, A.I.; López-Bote, C.; et al. Longissimus dorsi transcriptome analysis of purebred and crossbred Iberian pigs differing in muscle characteristics. $B M C$ Genomics 2014, 15, 413. [CrossRef] [PubMed]

142. Mizugishi, K.; Hatayama, M.; Tohmonda, T.; Ogawa, M.; Inoue, T.; Mikoshiba, K.; Aruga, J. Myogenic repressor I-mfa interferes with the function of Zic family proteins. Biochem. Biophys Res. Commun. 2004, 320, 233-240. [CrossRef]

143. Pan, H.; Gustafsson, M.K.; Aruga, J.; Tiedken, J.J.; Chen, J.C.; Emerson, C.P. A role for Zic1 and Zic2 in Myf5 regulation and somite myogenesis. Dev. Biol. 2011, 351, 120-127. [CrossRef]

144. Lei, H.; Leong, D.; Smith, L.R.; Barton, E.R. Matrix metalloproteinase 13 is a new contributor to skeletal muscle regeneration and critical for myoblast migration. Am. J. Physiol. Cell Physiol. 2013, 305, C529-C538. [CrossRef]

145. Yang, X.; Koltes, J.E.; Park, C.A.; Chen, D.; Reecy, J.M. Gene Co-Expression Network Analysis Provides Novel Insights into Myostatin Regulation at Three Different Mouse Developmental Timepoints. PLoS ONE 2015, 10, e0117607. [CrossRef]

146. Nesvadbova, M.; Borilova, G. Molecular regulation of skeletal muscle tissue formation and development. Vet. Med. 2018, 63, 489-499. [CrossRef]

147. Liu, H.; Xi, Y.; Liu, G.; Zhao, Y.; Li, J.; Lei, M. Comparative transcriptomic analysis of skeletal muscle tissue during prenatal stages in Tongcheng and Yorkshire pig using RNA-seq. Funct. Integr. Genomics 2018, 18, 195-209. [CrossRef]

148. Chen, X.; Luo, Y.; Huang, Z.; Jia, G.; Liu, G.; Zhao, H. Akirin2 regulates proliferation and differentiation of porcine skeletal muscle satellite cells via ERK1/2 and NFATc1 signaling pathways. Sci. Rep. 2017, 7, 45156. [CrossRef] [PubMed]

149. Reis, E.P.D.; Paixao, D.M.; Brustolini, O.J.; Silva, F.F.; Silva, W.; Araujo, F.M.; Matos Salim, A.C.; Oliveira, G.; Guimarães, S.E.F. Expression of myogenes in longissimus dorsi muscle during prenatal development in commercial and local Piau pigs. Genet. Mol. Biol. 2016, 39, 589-599. [CrossRef]

150. Qin, L.; Xu, J.; Wu, Z.; Zhang, Z.; Li, J.; Wang, C.; Long, Q. Notch1-mediated signaling regulates proliferation of porcine satellite cells (PSCs). Cell Signal. 2013, 25, 561-569. [CrossRef] [PubMed]

151. Li, M.; Wu, H.; Luo, Z.; Xia, Y.; Guan, J.; Wang, T.; Gu, Y.; Chen, L.; Zhang, K.; Ma, J.; et al. An atlas of DNA methylomes in porcine adipose and muscle tissues. Nat. Commun. 2012, 3, 850. [CrossRef] [PubMed]

152. Sun, Y.; Wang, P.; Zheng, H.; Smith, R.G. Ghrelin stimulation of growth hormone release and appetite is mediated through the growth hormone secretagogue receptor. Proc. Natl. Acad. Sci. USA 2004, 101, 4679-4684. [CrossRef] [PubMed] 
153. Jo, J.L.; Hwang, J.H.; Kwon, S.G.; Park, D.H.; Kim, T.W.; Kang, D.G.; Yu, G.E.; Kim, I.S.; Ha, J.G.; Kim, C.W. Association between a non-synonymous HSD17B4 single nucleotide polymorphism and meat-quality traits in Berkshire pigs. Genet. Mol. Res. 2016, 15, gmr15048970. [CrossRef]

154. Rehfelt, C.; Fiedler, I.; Stickland, N.C. Muscle development of livestock animals-Physiology, genetics and meat quality. In Number and Size of Muscle Fibres in Relation to Meat Production; Pas, M.F.W., Everts, M.E., Haagsman, H.P., Eds.; CABI Publishing: Cambridge, UK, 2004; pp. 1-30.

155. Gordon, E.S.; Gordish Dressman, H.A.; Hoffman, E.P. The genetics of muscle atrophy and growth: The impact and implications of polymorphisms in animals and humans. Int. J. Biochem. Cell Biol. 2005, 37, 2064-2074. [CrossRef]

156. Muñoz, M.; García-Casco, J.M.; Caraballo, C.; Fernández-Barroso, M.Á.; Sánchez-Esquiliche, F.; Gómez, F.; Rodríguez, M.D.C.; Silió, L. Identification of Candidate Genes and Regulatory Factors Underlying Intramuscular Fat Content Through Longissimus Dorsi Transcriptome Analyses in Heavy Iberian Pigs. Front. Genet. 2018, 9, 608. [CrossRef]

157. Lobjois, V.; Liaubet, L.; SanCristobal, M.; Glénisson, J.; Fève, K.; Rallières, J.; Roy, P.L.; Milan, D.; Cherel, P.; Hatey, F. A muscle transcriptome analysis identifies positional candidate genes for a complex trait in pig. Anim. Genet. 2008, 39, 147-162. [CrossRef] [PubMed]

158. Guo, X.; Li, M.; Gao, P.; Cao, G.; Zhang, W.; Liu, M.; Wang, H.; Qin, B.; Liu, J.; Wang, L.; et al. Identification of candidate genes of growth traits in pigs using RNA-sequencing. Ital. J. Anim. Sci. 2019, 18, 279-286. [CrossRef]

159. Levin, J.M.; Andalousi, R.A.; Dainat, J.; Reyne, Y.; Bacou, F. SFRP2 expression in rabbit myogenic progenitor cells and in adult skeletal muscles. J. Muscle Res. Cell Motil. 2001, 22, 361-369. [CrossRef]

160. Descamps, S.; Arzouk, H.; Bacou, F.; Bernardi, H.; Fedon, Y.; Gay, S.; Reyne, Y.; Rossano, B.; Levin, J. Inhibition of myoblast differentiation by Sfrp1 and Sfrp2. Cell Tissue Res. 2008, 332, 299-306. [CrossRef] [PubMed]

161. Xu, J.; Wang, C.; Jin, E.; Gu, Y.; Li, S.; Li, Q. Identification of differentially expressed genes in longissimus dorsi muscle between Wei and Yorkshire pigs using RNA sequencing. Genes Genomics 2018, 40, 413-421. [CrossRef] [PubMed]

162. Davey, J.R.; Watt, K.I.; Parker, B.L.; Chaudhuri, R.; Ryall, J.G.; Cunningham, L.; Qian, H.; Sartorelli, V.; Sandri, M.; Chamberlain, J.; et al. Integrated expression analysis of muscle hypertrophy identifies Asb2 as a negative regulator of muscle mass. JCI Insight 2016, 1, e85477. [CrossRef]

163. Wang, L.; Lei, M.; Xiong, Y. Molecular characterization and different expression patterns of the muscle ankyrin repeat protein (MARP) family during porcine skeletal muscle development in vitro and in vivo. Anim. Biotechnol. 2011, 22, 87-99. [CrossRef]

164. Ropka-Molik, K.; Pawlina-Tyszko, K.; Żukowski, K.; Piórkowska, K.; Żak, G.; Gurgul, A.; Derebecka, N.; Wesoły, J. Examining the Genetic Background of Porcine Muscle Growth and Development Based on Transcriptome and miRNAome Data. Int. J. Mol. Sci. 2018, 19, 1208. [CrossRef]

165. Yi, X.; Tao, Y.; Lin, X.; Dai, Y.; Yang, T.; Yue, X.; Jiang, X.; Li, X.; Jiang, D.; Andrade, K.C.; et al. Histone methyltransferase Setd2 is critical for the proliferation and differentiation of myoblasts. Biochim. Biophys. Acta Mol. Cell Res. 2017, 1864, 697-707. [CrossRef]

166. Zhu, B.; Zhang, M.; Byrum, S.D.; Tackett, A.J.; Davie, J.K. TBX2 blocks myogenesis and promotes proliferation in rhabdomyosarcoma cells. Int. J. Cancer 2014, 135, 785-797. [CrossRef]

167. Buzala, M.; Janicki, B. Review: Effects of different growth rates in broiler breeder and layer hens on some productive traits. Poult. Sci. 2016, 95, 2151-2159. [CrossRef]

168. Havenstein, G.B.; Ferket, P.R.; Qureshi, M.A. Carcass composition and yield of 1957 versus 2001 broilers when fed representative 1957 and 2001 broiler diets. Poult. Sci. 2003, 82, 1509-1518. [CrossRef]

169. Zheng, Q.; Zhang, Y.; Chen, Y.; Yang, N.; Wang, X.; Zhu, D. Systematic identification of genes involved in divergent skeletal muscle growth rates of broiler and layer chickens. BMC Genomics 2009, 10, 87. [CrossRef]

170. Ecarnot-Laubriet, A.; Luca, K.D.; Vandroux, D.; Moisant, M.; Bernard, C.; Assem, M.; Rochette, L.; Teyssier, J.R. Downregulation and nuclear relocation of MLP during the progression of right ventricular hypertrophy induced by chronic pressure overload. $J$. Mol. Cell Cardiol. 2000, 32, 2385-2395. [CrossRef]

171. Martin, B.; Schneider, R.; Janetzky, S.; Waibler, Z.; Pandur, P.; Kühl, M.; Behrens, J.; von der Mark, K.; Starzinski-Powitz, A.; Wixler, V. The LIM-only protein FHL2 interacts with beta-catenin and promotes differentiation of mouse myoblasts. J. Cell Biol. 2002, 159, 113-122. [CrossRef] [PubMed]

172. Kostek, M.C.; Chen, Y.; Cuthbertson, D.J.; Shi, R.; Fedele, M.J.; Esser, K.A.; Rennie, M.J. Gene expression responses over 24 h to lengthening and shortening contractions in human muscle: Major changes in CSRP3, MUSTN1, SIX1, and FBXO32. Physiol. Genomics 2007, 31, 42-52. [CrossRef]

173. Abarzua, F.; Sakaguchi, M.; Takaishi, M.; Nasu, Y.; Kurose, K.; Ebara, S.; Miyazaki, M.; Namba, M.; Kumon, H.; Huh, N. Adenovirus-mediated overexpression of REIC/Dkk-3 selectively induces apoptosis in human prostate cancer cells through activation of c-Jun-NH2-kinase. Cancer Res. 2005, 65, 9617-9622. [CrossRef] [PubMed]

174. Koppen, A.; Ait-Aissa, R.; Koster, J.; Øra, I.; Bras, J.; Sluis, P.G.; Caron, H.; Versteeg, R.; Valentijn, L.J. Dickkopf-3 expression is a marker for neuroblastic tumor maturation and is down-regulated by MYCN. Int. J. Cancer 2008, 122, 1455-1464. [CrossRef] [PubMed]

175. Yue, W.; Sun, Q.; Dacic, S.; Landreneau, R.J.; Siegfried, J.M.; Yu, J.; Zhang, L. Downregulation of Dkk3 activates beta-catenin/TCF-4 signaling in lung cancer. Carcinogenesis 2008, 29, 84-92. [CrossRef] 
176. Piórkowska, K.; Żukowski, K.; Połtowicz, K.; Nowak, J.; Ropka-Molik, K.; Derebecka, N.; Wesoły, J.; Wojtysiak, D. Identification of candidate genes and regulatory factors related to growth rate through hypothalamus transcriptome analyses in broiler chickens. BMC Genomics 2020, 21, 509. [CrossRef] [PubMed]

177. Nihashi, Y.; Umezawa, K.; Shinji, S.; Hamaguchi, Y.; Kobayashi, H.; Kono, T.; Ono, T.; Kagami, H.; Takaya, T. Distinct cell proliferation, myogenic differentiation, and gene expression in skeletal muscle myoblasts of layer and broiler chickens. Sci. Rep. 2019, 9, 16527. [CrossRef] [PubMed]

178. Waldemer-Streyer, R.J.; Reyes-Ordoñez, A.; Kim, D.; Zhang, R.; Singh, N.; Chen, J. Cxcl14 depletion accelerates skeletal myogenesis by promoting cell cycle withdrawal. NPJ Regen. Med. 2017, 2, 16017. [CrossRef]

179. Arber, S.; Halder, G.; Caroni, P. Muscle LIM protein, a novel essential regulator of myogenesis, promotes myogenic differentiation. Cell 1994, 79, 221-231. [CrossRef]

180. Chang, D.F.; Belaguli, N.S.; Iyer, D.; Roberts, W.B.; Wu, S.; Dong, X.; Marx, J.G.; Moore, M.S.; Beckerle, M.C.; Majesky, M.W.; et al. Cysteine-rich LIM-only proteins CRP1 and CRP2 are potent smooth muscle differentiation cofactors. Dev. Cell 2003, 4, 107-118. [CrossRef]

181. Al-Musawi, S.L.; Stickland, N.C.; Bayol, S.A. In ovo temperature manipulation differentially influences limb musculoskeletal development in two lines of chick embryos selected for divergent growth rates. J. Exp. Biol. 2012, 215 Pt 9, 1594-1604. [CrossRef]

182. Xue, Q.; Zhang, G.; Li, T.; Ling, J.; Zhang, X.; Wang, J. Transcriptomic profile of leg muscle during early growth in chicken. PLoS ONE 2017, 12, e0173824. [CrossRef] [PubMed]

183. Wiper-Bergeron, N.; Salem, H.A.; Tomlinson, J.J.; Wu, D.; Haché, R.J.G. Glucocorticoid-stimulated preadipocyte differentiation is mediated through acetylation of C/EBPbeta by GCN5. Proc. Natl. Acad. Sci. USA 2007, 104, 2703-2708. [CrossRef] [PubMed]

184. Marchildon, F.; Lala, N.; Li, G.; St-Louis, C.; Lamothe, D.; Keller, C.; Wiper-Bergeron, N. CCAAT/enhancer binding protein beta is expressed in satellite cells and controls myogenesis. Stem Cells 2012, 30, 2619-2630. [CrossRef]

185. Cui, T.X.; Lin, G.; Lapensee, C.R.; Calinescu, A.A.; Rathore, M.; Streeter, C.; Piwien-Pilipuk, G.; Lanning, N.; Jin, H.; Carter-Su, C.; et al. C/EBP $\beta$ mediates growth hormone-regulated expression of multiple target genes. Mol. Endocrinol. 2011, 25, 681-693. [CrossRef]

186. Nicolae, D.L.; Gamazon, E.; Zhang, W.; Duan, S.; Dolan, M.E.; Cox, N.J. Trait-associated SNPs are more likely to be eQTLs: Annotation to enhance discovery from GWAS. PLoS Genet. 2010, 6, e1000888. [CrossRef]

187. Xie, L.; Luo, C.; Zhang, C.; Zhang, R.; Tang, J.; Nie, Q.; Ma, L.; Hu, X.; Li, N.; Da, Y.; et al. Genome-wide association study identified a narrow chromosome 1 region associated with chicken growth traits. PLoS ONE 2012, 7, e30910. [CrossRef]

188. Kamei, Y.; Miura, S.; Suzuki, M.; Kai, Y.; Mizukami, J.; Taniguchi, T.; Mochida, K.; Hata, T.; Matsuda, J.; Aburatani, H.; et al. Skeletal muscle FOXO1 (FKHR) transgenic mice have less skeletal muscle mass, down-regulated Type I (slow twitch/red muscle) fiber genes, and impaired glycemic control. J. Biol. Chem. 2004, 279, 41114-41123. [CrossRef]

189. Kitamura, T.; Kitamura, Y.I.; Funahashi, Y.; Shawber, C.J.; Castrillon, D.H.; Kollipara, R.; DePinho, R.A.; Kitajewski, J.; Accili, D. A Foxo/Notch pathway controls myogenic differentiation and fiber type specification. J. Clin. Investig. 2007, 117, 2477-2485. [CrossRef]

190. Yuan, Y.; Shi, X.E.; Liu, Y.G.; Yang, G.S. FoxO1 regulates muscle fiber-type specification and inhibits calcineurin signaling during C2C12 myoblast differentiation. Mol. Cell Biochem. 2011, 348, 77-87. [CrossRef] [PubMed]

191. Gu, X.; Feng, C.; Ma, L.; Song, C.; Wang, Y.; Da, Y.; Li, H.; Chen, C.; Ye, S.; Ge, C.; et al. Genome-wide association study of body weight in chicken F2 resource population. PLoS ONE 2011, 6, e21872. [CrossRef] [PubMed]

192. Liu, R.; Sun, Y.; Zhao, G.; Wang, H.; Zheng, M.; Li, P.; Liu, L.; Wen, J. Identification of loci and genes for growth related traits from a genome-wide association study in a slow- $\times$ fast-growing broiler chicken cross. Genes Genomics 2015, 37, 829-836. [CrossRef]

193. Liu, R.; Sun, Y.; Zhao, G.; Wang, F.; Wu, D.; Zheng, M.; Chen, J.; Zhang, L.; Hu, Y.; Wen, J. Genome-wide association study identifies Loci and candidate genes for body composition and meat quality traits in Beijing-You chickens. PLoS ONE 2013, 8 , e61172. [CrossRef]

194. Lei, M.; Peng, X.; Zhou, M.; Luo, C.; Nie, Q.; Zhang, X. Polymorphisms of the IGF1R gene and their genetic effects on chicken early growth and carcass traits. BMC Genet. 2008, 9, 70. [CrossRef]

195. Lei, M.M.; Nie, Q.H.; Peng, X.; Zhang, D.X.; Zhang, X.Q. Single nucleotide polymorphisms of the chicken insulin-like factor binding protein 2 gene associated with chicken growth and carcass traits. Poult. Sci. 2005, 84, 1191-1198. [CrossRef]

196. Sato, S.; Ohtake, T.; Uemoto, Y.; Okumura, Y.; Kobayashi, E. Polymorphism of insulin-like growth factor 1 gene is associated with breast muscle yields in chickens. Anim. Sci. J. 2012, 83, 1-6. [CrossRef]

197. Ouyang, J.H.; Xie, L.; Nie, Q.; Luo, C.; Liang, Y.; Zeng, H.; Zhang, X. Single nucleotide polymorphism (SNP) at the GHR gene and its associations with chicken growth and fat deposition traits. Br. Poult. Sci. 2008, 49, 87-95. [CrossRef]

198. Nie, Q.; Fang, M.; Xie, L.; Zhou, M.; Liang, Z.; Luo, Z.; Wang, G.; Bi, W.; Liang, C.; Zhang, W.; et al. The PIT1 gene polymorphisms were associated with chicken growth traits. BMC Genet. 2008, 9, 20. [CrossRef]

199. Fang, M.; Nie, Q.; Luo, C.; Zhang, D.; Zhang, X. Associations of GHSR gene polymorphisms with chicken growth and carcass traits. Mol. Biol. Rep. 2010, 37, 423-428. [CrossRef] [PubMed]

200. Fang, M.; Nie, Q.; Luo, C.; Zhang, D.; Zhang, X. An 8bp indel in exon 1 of Ghrelin gene associated with chicken growth. Domest. Anim. Endocrinol. 2007, 32, 216-225. [CrossRef]

201. Zhang, G.X.; Zhao, X.H.; Wang, J.Y.; Ding, F.X.; Zhang, L. Effect of an exon 1 mutation in the myostatin gene on the growth traits of the Bian chicken. Anim. Genet. 2012, 43, 458-459. [CrossRef] [PubMed] 
202. Zhou, Y.; Liu, Y.; Jiang, X.; Du, H.; Li, X.; Zhu, Q. Polymorphism of chicken myocyte-specific enhancer-binding factor 2A gene and its association with chicken carcass traits. Mol. Biol. Rep. 2010, 37, 587-594. [CrossRef] [PubMed]

203. Yin, H.; Zhang, Z.; Lan, X.; Zhao, X.; Wang, Y.; Zhu, Q. Association of MyF5, MyF6 and MyoG gene polymorphisms with carcass traits in Chinese Meat Type Quality chicken populations. J. Anim. Vet. Adv. 2011, 10, 704-708. [CrossRef]

204. Zhang, S.; Han, R.L.; Gao, Z.Y.; Zhu, S.K.; Tian, Y.D.; Sun, G.R.; Kang, X.T. A novel 31-bp indel in the paired box 7 (PAX7) gene is associated with chicken performance traits. Br. Poult. Sci. 2014, 55, 31-36. [CrossRef] [PubMed]

205. Moazeni, S.M.; Mohammadabadi, M.; Sadeghi, M.; Moradi Shahrbabak, H.; Esmailizadeh Koshkoieh, A.; Bordbar, F. Association between UCP Gene Polymorphisms and Growth, Breeding Value of Growth and Reproductive Traits in Mazandaran Indigenous Chicken. Open J. Anim. Sci. 2016, 6, 1-8. [CrossRef]

206. Rudofsky, G.; Schroedter, A.; Schlotterer, A.; Voron'ko, O.E.; Schlimme, M.; Tafel, J.; Isermann, B.H.; Humpert, P.M.; Morcos, M.; Bierhaus, A.; et al. Functional Polymorphisms of UCP 2 and UCP 3 Are Associated with a Reduced Prevalence of Diabetic Neuropathy in Patients with Type 1 Diabetes. Diabetes Care 2006, 29, 89-94. [CrossRef]

207. Chen, B.; Xu, J.; He, X.; Xu, H.; Li, G.; Du, H.; Nie, Q.; Zhang, X. A genome wide mRNA screen and functional analysis reveal FOXO3 as a candidate gene for chicken growth. PLoS ONE 2015, 10, e0137087. [CrossRef]

208. Luo, W.; Lin, S.; Li, G.; Nie, Q.; Zhang, X. Integrative analyses of miRNA-mRNA interactions reveal let-7b, miR-128 and MAPK pathway involvement in muscle mass loss in sex-linked dwarf chickens. Int. J. Mol. Sci. 2016, 17, 276. [CrossRef] [PubMed]

209. Lin, S.; Li, H.; Mu, H.; Luo, W.; Li, Y.; Jia, X.; Wang, S.; Jia, X.; Nie, Q.; Li, Y.; et al. Let-7b regulates the expression of the growth hormone receptor gene in deletion-type dwarf chickens. BMC Genomics 2012, 13, 306. [CrossRef] [PubMed]

210. Jia, X.; Lin, H.; Abdalla, B.A.; Nie, Q. Characterization of miR-206 promoter and its association with birthweight in chicken. Int. J. Mol. Sci. 2016, 17, 559. [CrossRef] [PubMed]

211. Luo, W.; Wu, H.; Ye, Y.; Li, Z.; Hao, S.; Kong, L.; Zheng, X.; Lin, S.; Nie, Q.; Zhang, X. The transient expression of miR-203 and its inhibiting effects on skeletal muscle cell proliferation and differentiation. Cell Death Dis. 2014, 5, e1347. [CrossRef]

212. Luo, W.; Li, G.; Yi, Z.; Nie, Q.; Zhang, X. E2F1-miR-20a-5p/20b-5p auto-regulatory feedback loop involved in myoblast proliferation and differentiation. Sci. Rep. 2016, 6, 27904. [CrossRef] [PubMed] 